\begin{tabular}{|l|r|}
\hline \multicolumn{1}{|c|}{ S sciendo } & \begin{tabular}{c} 
NCF $\begin{array}{l}\text { Nordic } \\
\text { Concrete } \\
\text { Federation }\end{array}$ \\
\hline $\begin{array}{l}\text { (C) Article authors. This is an open access article distributed under } \\
\text { the Creative Commons Attribution-NonCommercial-NoDerivs } \\
\text { licens. (http://creaticecommons.org/licenses/by.nc-nd/3.0/). }\end{array}$
\end{tabular} \\
\hline & $\begin{array}{r}\text { ISSN online 2545-2819 } \\
\text { ISSN print } \quad 0800-6377\end{array}$ \\
DOI: $10.2478 /$ ncr-2021-0002 & $\begin{array}{r}\text { Received: March 15, } 2021 \\
\text { Revision received: June 15, } 2021\end{array}$ \\
& Accepted: June 16, 2021 \\
\hline
\end{tabular}

\title{
Applicability of Existing Crack Controlling Criteria for Structures with Large Concrete Cover Thickness
}

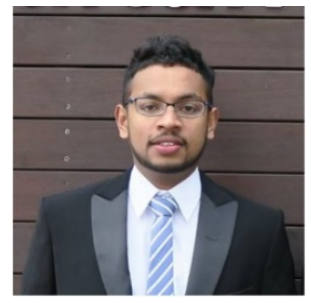

Chavin Nilanga Naotunna - Corresponding Author.

$\mathrm{PhD}$ Candidate.

University of Stavanger, Department of Mechanical and Structural

Engineering and Material Science, Stavanger.

Address: Kjell Arholmsgate 41, 4036 Stavanger, Norway.

E-mail: chavin.guruge@uis.no

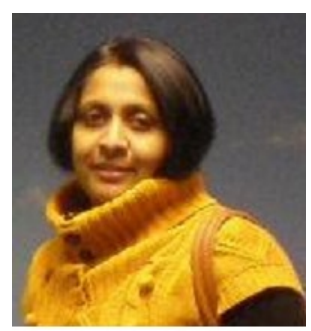

S.M Samindi M.K Samarakoon.

Associate Professor.

University of Stavanger, Department of Mechanical and Structural

Engineering and Material Science, Stavanger.

Address: Kjell Arholmsgate 41, 4036 Stavanger, Norway.

E-mail: samindi.samarakoon@uis.no

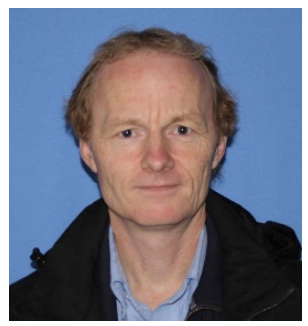

Kjell Tore Fosså.

Adjunct Professor.

University of Stavanger, Department of IMBM.

Manager Concrete Technology.

Aker Solutions, Stavanger, NO 4020.

E-mail: kjell.t.fossa@uis.com

\begin{abstract}
Widely used crack width calculation models and allowable crack width limits have changed from time to time and differ from region to region. It can be identified that some crack width calculation models consist with limitations for parameters like cover thickness. The current Norwegian requirement for cover thickness is larger than these limitations. The applicability of existing crack width calculation models and the allowable crack width limits must be verified for structures with large cover thickness. The background of crack width calculation models in Eurocode, Model Code 2010, Japanese code, American code and British code have been examined. By comparing the experimental crack widths with the predictions of the aforementioned models, the existing codes can be identified as requiring modification. Considering the durability aspect, it can be identified a long-term study proving that the allowable crack width can be increased with the increase in cover thickness. When considering the aesthetic aspect, the authors suggest
\end{abstract}


categorizing the structures based on their prestige level and deciding the allowable crack widths accordingly. The paper proposes potential solutions for future research on how to improve both crack width calculation methods and allowable crack width limits to be used effectively in structures with large cover thickness.

Keywords - reinforced concrete structures, service load, crack width, durability, aesthetic, concrete cover thickness

1. INTRODUCTION

Cracks in concrete occur when the tensile stress on concrete exceeds its tensile strength [1]. The cracks in reinforced concrete (RC) structures create many adverse effects on the durability, aesthetic view and liquid or gas tightness of the structure. To avoid the discussed adverse effects from cracks, it is necessary to repair the cracks, resulting in high repair costs [2]. Therefore, it is always preferable to limit cracks at the structural design stage. On the other hand, it is not possible to control all types of cracks at this stage. Depending on the controllability of the cracks at the structural design stage, Beeby [3] has classified cracks as controllable (load-induced cracks) and non-controllable (cracks caused by plastic shrinkage, alkali-silica reaction, freeze/thaw deterioration). To minimize the occurrence of cracks due to service load, the 'stress of the tensile steel' has to be limited to a low value. According to the Japanese code, for the RC structures with deformed bars, if the tensile stress due to permanent loads has limited to $120 \mathrm{~N} / \mathrm{mm}^{2}$, the examination of crack widths may be omitted [4]. In order to do this, a large amount of reinforcement is required. This tends to drastically increase the cost of the structure and reduce the ease of construction. Therefore, in general, cracks due to service load are allowed to occur and are controlled by limiting crack widths.

At the design stage, the 'calculated crack width' is limited to an 'allowable crack width' [5-8]. These 'calculated crack width' models have changed from time to time and differ from region to region. For example, crack width calculation models have changed from CEB Model Code 78 [9] to CEB/FIP Model Code 90 [5] and similarly from Eurocode 2 (1991) [10] to the current Eurocode 2 [7]. Furthermore, crack width calculation models in different regions differ from each other, as they are based on different approaches. Empirically based crack width calculation models are found in the American Concrete Institute (ACI) code [8], British Standards (BS) code [11], Gergely and Lutz [12], Kaar and Hognestad [13], Sygula [14] and so on. Crack width calculation models based on a semi-analytical approach are in Eurocode 2 (EC2) [7], CEB/FIP Model Code 90 [5], Model Code 2010 (MC2010) [6], the Japanese Society of Civil Engineers (JSCE) code [4], the Architectural Institute of Japan (AIJ) [15], and so on. Widely used analytically based crack width calculation models can be found in Balazs [16], Tan et al. [17], Oh and Kang [18] and so on.

As mentioned, there are several crack width calculation models available in the literature. However, it is vital to study their limitations. For example, the MC2010 crack width calculation model limits concrete cover thickness to $75 \mathrm{~mm}$. However, recently, the economic and social benefits over the long term of structures with a significantly long service life (200 or 300 years) have been identified $[19,20]$. Concrete cover thickness is mainly increased to satisfy the durability aspect, when a long service life is required for an RC structure. The current requirement of concrete cover thickness is as high as $120 \mathrm{~mm}$ (Norwegian Public Road Administration guidelines [21]); as an example, Hafrsfjord Bridge in Norway is constructed with a concrete cover thickness of $90 \mathrm{~mm}[22,23]$. As mentioned, some 'crack width calculation' models have limitations for concrete cover thickness. Further, it is important to check the applicability of existing models, as they have not been validated for such structures with large concrete cover thickness.

Similar to the crack width calculation models, it can be seen that the 'allowable crack width limits' in the widely used codes of practice have changed from time to time and differ from each other. For example, CEB Model Code 78 [9] prescribes limiting the crack width in severe conditions to $0.1 \mathrm{~mm}$; this value has been changed in CEB/FIP Model Code 90 [5] and MC2010 [6] to $0.3 \mathrm{~mm}$. Further, in severe conditions, all the EC2, MC2010 and BS codes prefer to limit the crack width to $0.3 \mathrm{~mm}$, while ACI 224 [24] and ACI 
318 [8] prefer to limit the crack width to $0.15 \mathrm{~mm}$ and $0.33 \mathrm{~mm}$, respectively. In severe conditions, these limits are mainly decided on to protect the reinforcement from corrosion [1]. When referring to previous long-term studies on crack widths and corrosion, it can be seen that the allowable crack width can be increased with the increase in concrete cover thickness [25]. The allowable crack width limits in the JSCE code are an example of such application. Apart from the durability considerations, the thickness of the concrete cover depends on the safe transmission of bond properties and is based on fire resistance. For example, according to EC2, for the safe transmission of bond forces, concrete covers can be as large as 55 $\mathrm{mm}$ for cases with bundled bars [7]. Therefore, even for structures which are not built-in severe exposure classes, there is the possibility to have relatively large covers. This shows the necessity to revisit the allowable crack width limits, based on aesthetic acceptance, for structures with large concrete cover thicknesses. If the crack width of a structure with a large concrete cover thickness is controlled to the allowable limits which are prescribed for lower cover thicknesses, additional tensile reinforcement tends to be required. For this reason, it is necessary to identify how the existing allowable limits are decided and what improvements need to be made for them to apply to structures with higher cover thicknesses.

This paper focuses on the applicability of existing 'crack width calculation models' and existing 'allowable crack width limits', for structures with large concrete cover thickness. The manuscript starts with a discussion of the cracking phenomenon. Then, it explains the background to why the different codes of practice suggest different models to calculate the crack width. By comparing the recent experimental results with the model predictions, this study emphasizes the necessity to improve existing crack width calculation models, to effectively predict the crack width of structures with large concrete covers. The next objective is to identify the applicability of existing 'allowable crack width limits' for structures with large concrete covers. An extensive literature survey has been carried out on how the existing limitation has been appointed, based on durability and aesthetic view. The required improvements and the further studies needed to decide the 'allowable crack width limits', to apply to structures with large concrete cover thickness, have been identified.

\section{CRACKING PHENOMENON OF RC MEMBERS SUBJECTED TO SERVICE LOAD}

To understand the cracking phenomenon in flexure, a reinforced concrete $(\mathrm{RC})$ tie in pure tension can be considered, as it can represent the tensile region of a bending member with or without any axial force [26, 27]. Many previous researchers have identified the cracking behaviour of RC specimens subjected to pure tension [28-32]. Figure 1 represents the cracking behaviour of an $\mathrm{RC}$ tie subjected to pure tension, according to Beeby [33]. The stress in the rebar starts affecting the concrete surface after ' $\mathrm{KC}$ ' (' $\mathrm{K}$ ' is a constant and ' $\mathrm{C}$ ' is cover) distance [34-36] from the specimen end, and it takes another $\mathrm{S}_{0}$ distance to uniformly distribute the stress along the cross section. When the applied force increases from zero, the highest stress occurs at the concrete surface after $\mathrm{KC}+\mathrm{S}_{\mathrm{o}}$ distance (transfer length) and beyond. This theoretical explanation matches the 'combined theory' introduced by Borges [37]. Borges considered the cracking behaviour to be in accordance with the combination of the two main theories: 'no-slip' theory $[28,38,39]$ and 'bond-slip' theory [40-42]. A detailed description of these theories can be seen in Naotunna et al's study [43]. When the stress in the concrete cross section reaches the tensile strength $\left(\mathrm{f}_{\mathrm{ct}}\right)$, the first crack appears. After the first crack, the stress/strain distribution rearranges, as, at the crack, the concrete can no longer withstand tensile stress perpendicular to the crack face (Figure 1 (b)). When the load is further increased, another crack occurs after the transfer length. This proceeds until the last crack occurs and then transfers to the stabilized cracking stage. At this stage, the increased strain due to the further increased load accumulates at the cracks that have already occurred. 


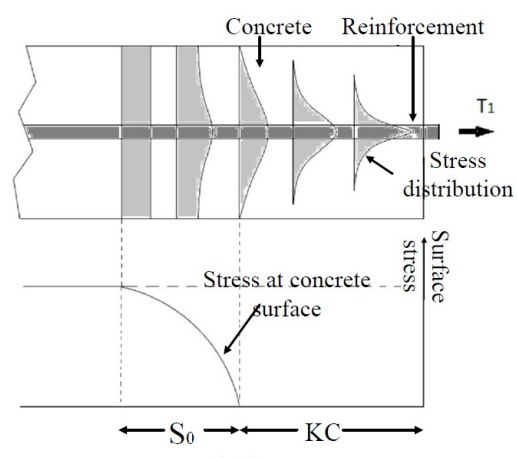

( a )

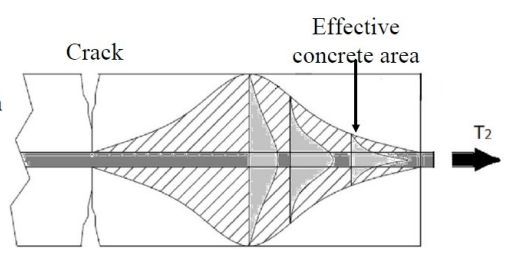

( b )

Figure 1 - (a) Internal stress distribution \& surface stress variation of an $R C$ tie before cracking, (b) Internal stress distribution of a cracked RC tie.

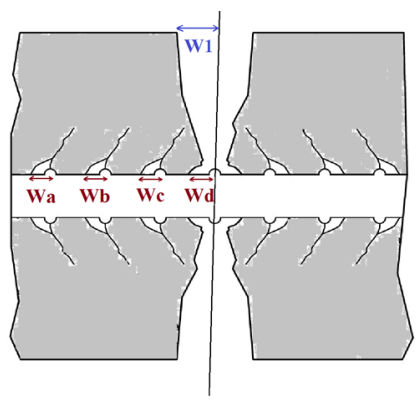

$\mathbf{W a}+\mathrm{Wb}+\mathrm{Wc}+\mathbf{W d} \approx \mathrm{W}_{1}$

Figure 2 - Crack width variation along the concrete cover.

The aforementioned explanation of the cracking is a simplified approach. As shown in Figure 1(b), a strain incompatibility can be observed between reinforcement and concrete, specially at the vicinity of reinforcement [44]. In the specimens with deformed reinforcement, the strain incompatibility is accommodated in the internal cracks (secondary cracks) [26, 32, 44, 45]. Even though these cracks do not completely discontinue the concrete material, a partial discontinuity occurs [46]. This leads to a complicated stress/strain distribution throughout the specimen because concrete is an inhomogeneous material. The tensile strength of concrete is not the same, even in different samples of the same batch of concrete [47]. The variation of the tensile strength of concrete complicates the strain incompatibility. Naotunna et al. [48] have suggested including the lower and upper fractile values of concrete tensile strengths, to identify the minimum and maximum crack spacing values. The cracking phenomenon would be more complicated with conditions like effective concrete area, inhomogeneous behaviour of concrete, tension stiffening effect, internal cracking (Goto cracks) and so on.

\section{CALCULATION OF CRACK WIDTHS}

There are various types of crack width calculation models in the existing literature. The theoretical concept of crack width is the integration of the actual strain difference of reinforcement and concrete between two cracks [16]. The crack width at the tensile reinforcement can be calculated by using Equation (1). However, due to the nonlinear behaviour of strain variation in both concrete and reinforcement between two cracks, obtaining the crack width explicitly is a complicated process [27]. Therefore, in order to make the crack width calculation model less complicated or more user-friendly, many codes use simplified or semianalytical approaches. Examples of such models are found in EC2 [7], MC2010 [6], JSCE [4] code and so on. On the other hand, codes like ACI [8] and BS [11] use crack width calculation models based on empirical approaches. Such models are developed by curve fitting of a considerable amount of experimental data. The ACI and BS codes were developed by the experimental investigation of Gergely and Lutz [49] and Beeby [50], respectively.

$w=\int_{0}^{s_{r}} \varepsilon_{s}-\varepsilon_{c} d x$

where ' $\mathrm{w}$ ' is the crack width, ' $\mathrm{S}_{\mathrm{r}}$ ' is the crack spacing, and ' $\varepsilon_{\mathrm{s}}$ ' and ' $\varepsilon_{\mathrm{c}}$ ' are the strains of reinforcement and concrete in the $\mathrm{x}$-direction (the direction of axial tensile load).

Semi-analytical models developed from Equation (1) predict the crack width at the tensile reinforcement surface [51]. It is assumed that the crack width propagates similarly, along with the concrete cover thickness, and therefore the same model is used to predict the crack width at the concrete surface $[6,7]$. However, the experimental investigations in [51-54] have identified that the crack width at the concrete 
surface is two to ten times larger than the crack width at the reinforcement bar. Beeby and Scott [44] observed that the reason for this crack width difference is the effect of shear lag, which occurs along with the concrete cover. However, Caldentey et al. [55] have proved with calculations that the effect of shear lag is considerably smaller than the aforementioned crack width difference at the reinforcement and concrete surface. The authors in [51, 55] explained that the reason for the crack width difference is the presence of Goto cracks [32] (secondary cracks). These secondary cracks are spread at the vicinity of the primary cracks $[26,32,56]$. As the strain accumulates in the secondary cracks, the width of the primary crack at the reinforcement is reduced. Therefore, as per Figure 2, it can be concluded that the predictions of semi-analytical models in $[6,7]$ are similar to the surface crack width.

Semi-analytical models based on Equation (1) predict the crack width by multiplying the crack spacing with the strain difference between reinforcement and concrete. Many studies have identified that it is vital to improve the 'crack spacing' model, in order to improve the crack width calculation models [57-59]. Tammo and Thelandersson [57] proved that changing the concrete properties makes no difference to the surface crack width or internal crack widths, if the crack spacing values are the same. The crack spacing models in the semi-analytical models are based on the aforementioned two main theories: 'bond-slip' and 'no-slip' theories. According to the bond-slip theory, since a 'slip' is assumed at the reinforcementconcrete interface, a bond-stress would generate. Therefore, the governing crack spacing parameters from this theory are bond parameter (' $\varnothing / \rho$ '; where ' $\varnothing$ ' is the bar diameter and ' $\rho$ ' is the ratio between reinforcement area and concrete area), bond stress, etc. [26, 45]. The German National Annex of EC2 [60] proposes a model based on the bond-slip approach. According to the no-slip theory, the governing crack spacing parameters can be considered to be concrete cover thickness and the distance between tensile reinforcement (thickness of the surrounding concrete of the tensile reinforcement) [28, 61]. The crack spacing model in the Japanese code and Beeby's model in Beeby and Scott [44] are some examples of crack spacing models based on no-slip theory. The EC2 and MC2010 models are based on the combined theory, which considers the cracking behaviour to be based on the combination of the aforementioned two theories.

\subsection{Crack Width Calculation Methods In Widely Used Codes Of Practice}

Several widely used crack width prediction models in the codes of practice have been examined. Prediction models have been selected, as they can represent the different regions of the world. EC2 and MC2010 have been selected, as they are the governing codes of practice in Europe. Then the crack width prediction models in American code, Japanese code and British code have been considered. When examining the models proposed by codes, it can be observed that some codes mention limitations for the concrete cover thickness. MC2010 limits the applicability of the crack width calculation model to $75 \mathrm{~mm}$ cover thickness. Since the focus of this study is to check the applicability of existing crack controlling criteria for specimens with large concrete cover thickness, the background of these widely used crack width calculation models has been investigated and is presented, along with detailed desctiptions, in Table 1. From the models proposed by the codes in Table 1, various crack width governing parameters can be identified. A detailed list of such parameters and their involvement in crack width can be identified from the literature [62].

Figure 3 categorizes all the crack width governing parameters mentioned in the aforementioned widely used crack width prediction models. The crack width governing parameters have been categorized based on the mechanical properties of concrete and reinforcement, properties of interface, cross-sectional properties of the RC member and loading conditions. From Table 1, it can be identified that the EC2, MC2010 and JSCE code models, which are based on a semi-analytical approach, consider a higher number of parameters than the empirically based ACI and BS code models. Further, it is clear that, although the mentioned models have been developed based on different approaches, the concrete cover thickness parameter is included in every model. The calculated crack width from these models causes the crack width to increase with the increase in concrete cover. The models in EC2 and MC2010 specifically mention their 
applicable limitations for concrete cover thickness. The models in the JSCE, ACI and BS codes do not mention such limitations. The main reason could be that the commonly used concrete cover thickness in the period of developing the code might not be as large as the current requirement. It is important to note that the empirically based crack width calculation models developed by the ACI and BS codes have considered test specimens with concrete cover thicknesses of $84 \mathrm{~mm}$ and $89 \mathrm{~mm}$, respectively. However, as mentioned in Section 1, there is a demand for large concrete cover thickness [21].

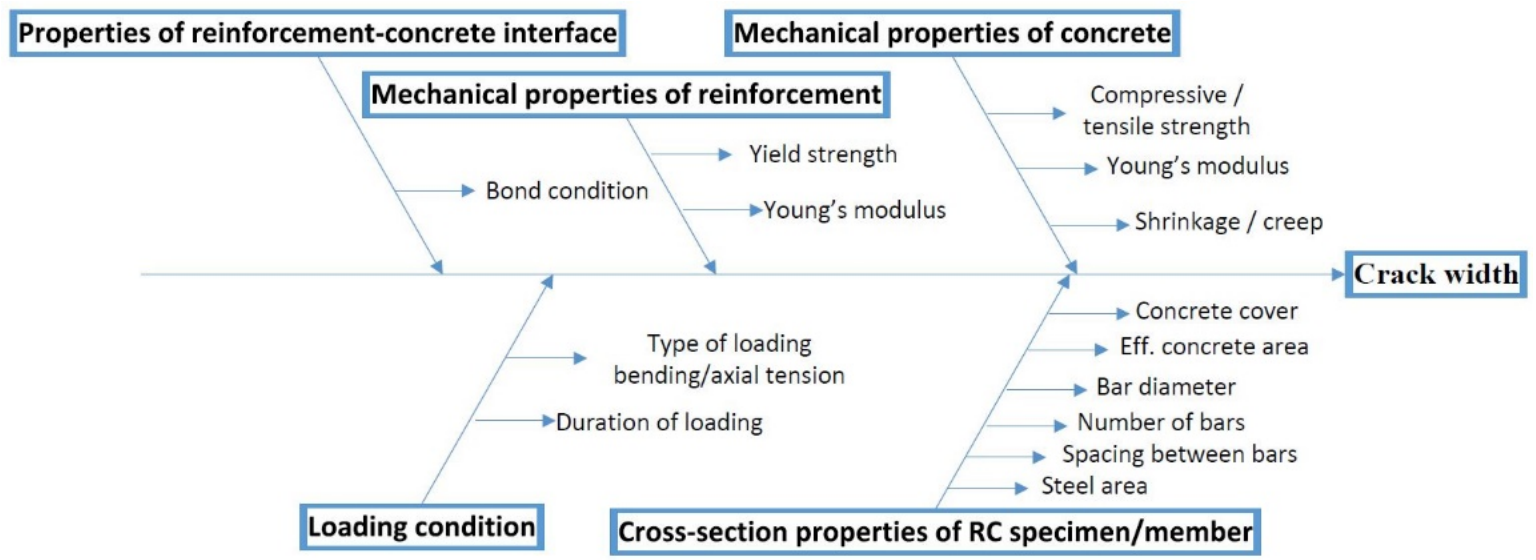

Figure 3. Cause and effect diagram for crack width.

\section{2}

\section{Improvements to the existing crack width prediction models}

From Table 1, it is clear that MC2010 mentions limitations for the concrete cover thickness. Further, according to the literature on recent experiments, many cases can be identified in which the experimental values deviate from the EC2 and MC2010 predictions [27, 48, 63-68]. Therefore, many improvements have been proposed for these two models, some of which are listed in Table 2. According to these suggested improvements, it can be identified that none of the improved models has compared the data with specimens having cover thickness of above $70 \mathrm{~mm}$. Therefore, the applicability of the aforementioned improved models needs to be verified for concrete covers larger than $70 \mathrm{~mm}$.

Identifying the crack theory which is most related to the actual cracking behaviour is vital, since the crack spacing governing parameters can be identified based on them. The recent study, published in 2021 by Bado et al. [69], has focused attention on the 'slip' values in axial tensile experiments. In this study, the slip at the reinforcement-concrete interphase is measured by optical fibre sensors. Further, these findings of Bado et al. [69] match the experimental results of previous studies conducted on the bond-slip behaviour of axial-tensile experiments by Doerr [70] and Beconcini and Croce [71]. According to the findings of these studies, the slip values in axial tension are quite negligible compared to the predictions in the widely used Eligehausen's model [72, 73]. The Eligehausen's bond-slip model is considered in MC 2010, and this model is based on the Rilem type pull-out tests [74]. Moreover, Balazs [16] has used Eligehausen's model to model the bond-slip behaviour while developing a crack width calculation model. Further, in the widely used Finite Element Modelling software like, ATENA [75], considers this Eligehausen's bond-slip model to model the cracking behaviour in RC members. However, as shown in Figure 4, the slip values in axial tension are significantly smaller than the slip values suggested by Eligehausen's bond-slip model (same bond-slip model used in MC 2010). Since it has observed a negligible amount of slip in the RC specimens in axial tension, the applicability of bond-slip law on crack spacings can be considered questionable. Furthermore, there are several experimental studies which make similar arguments, that the bondparameter (' $\varnothing / \rho$ ' which is the dominant parameter in the bond-slip law) has little influence on crack spacings when the concrete cover is small. Such experimental studies are mentioned in Base et al. [38], Caldentey et al. [55] (for specimens with $70 \mathrm{~mm}$ covers), Rimkus et al. [63], and Kim et al. [76]; analytical studies are mentioned in Beeby [40], and Beeby and Scott [44]. Naotunna et al. [43, 77], have further discussed this scenario. 
Table 1 - Crack width calculation models in widely used codes of practice and their significances

\begin{tabular}{|c|c|c|}
\hline $\begin{array}{l}\text { Model } \\
\text { EC2 [7] } \\
\text { and } \\
\text { MC2010 } \\
{[6]}\end{array}$ & odels & \\
\hline \multirow{3}{*}{$\begin{array}{l}\text { EC2 [7] } \\
\text { and } \\
\text { MC2010 } \\
{[6]}\end{array}$} & $\begin{array}{l}\mathrm{W}_{\mathrm{k}}=\text { Maximum crack spacing } \times \text { Mean strain difference of rebar } \\
\text { and concrete }\end{array}$ & Semi-analytical models \\
\hline & $\begin{array}{l}\text { Maximum crack spacing } \\
\begin{aligned} & \text { EC2 Model } \text { MC2010 transfer length } \\
& \text { Model } \\
& \mathrm{Sr}, \max =\mathrm{k}_{3} \mathrm{c}+\mathrm{k}_{1} \mathrm{k}_{2} \mathrm{k}_{4} \varnothing / \rho_{\mathrm{p}, \mathrm{eff}} 1_{\mathrm{s}, \max }= \\
& \mathrm{kc}+(1 / 4)\left(\mathrm{f}_{\mathrm{ctm}} / \tau_{\mathrm{bms}}\right)\left(\varnothing_{\mathrm{s}} / \rho_{\mathrm{s}, \mathrm{ef}}\right)\end{aligned} \\
\text { where 'c' is concrete cover, ' } \rho_{\mathrm{s}, \mathrm{ef}} \text { ' is effective steel ratio, ' } \mathrm{k}_{1} \text { ' is } \\
\text { factor for bond properties, ' } \mathrm{k} 2 \text { ' is factor for distribution of strain, } \\
\text { ' } \mathrm{k}_{3} \text { ' is recommended as } 3.4 \text {, ' } \mathrm{k} 4 \text { ' is recommended as } 0.425 \text {, ' } \mathrm{k} \text { ' } \\
\text { is empirical parameter on cover, ' } \tau_{\mathrm{bms}} \text { ' is mean bond strength } \\
\text { (steel-concrete), ' } \varnothing_{\mathrm{s}} \text { ' is the bar diameter, and ' } \mathrm{f}_{\mathrm{ctm}} \text { ' is the tensile } \\
\text { strength of concrete. }\end{array}$ & $\begin{array}{l}\text { Assumptions: From the different bond stress } \\
\text { models for reinforcement and concrete (linear, } \\
\text { non-linear) between a crack and a no-slip location } \\
{[41,42,78,79] \text {, a constant mean bond stress has }} \\
\text { been assumed [80]. } \\
\text { Significance: EC2 uses a ' } k \text { ' factor to take into } \\
\text { account the variation in strain distributions } \\
\text { (flexural or axial tension) [81], and MC2010 } \\
\text { considers that only the 'effective concrete area' } \\
\text { can represent the effect [82]. } \\
\text { Limitations for cover: MC2010 limits to } 75 \mathrm{~mm} \text {. }\end{array}$ \\
\hline & 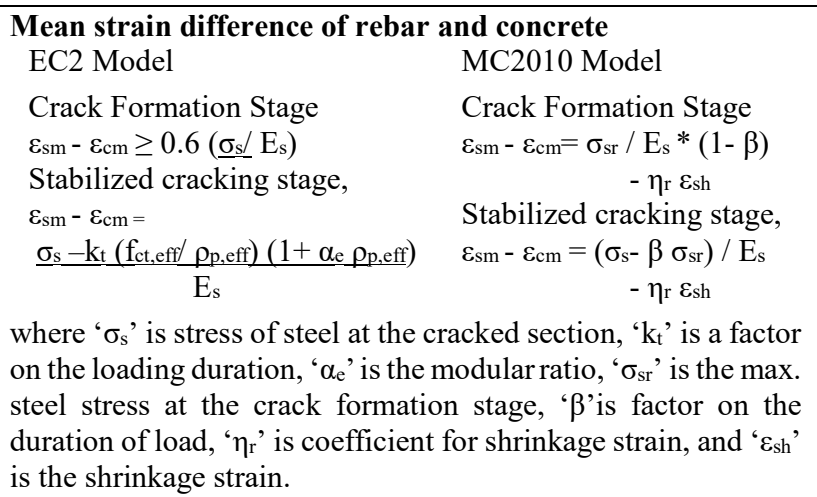 & $\begin{array}{l}\text { Concrete cannot further increase its strain when } \\
\text { the total number of cracks has formed (as the } \\
\text { available length to develop stress in concrete is } \\
\text { fixed). Therefore, when the strain of the steel is } \\
\text { further increased (when it reaches the stabilized } \\
\text { cracking stage), the concrete strain remains } \\
\text { unchanged. This causes there to be different } \\
\text { formulas for the mean strain difference between } \\
\text { reinforcement and concrete in both cracking } \\
\text { stages. Significance: Except for the effect of } \\
\text { shrinkage considered in the MC2010 model, both } \\
\text { EC2 and MC2010 use the same equation in the } \\
\text { stabilized cracking stage. }\end{array}$ \\
\hline $\begin{array}{l}\text { JSCE } \\
\text { code [4] }\end{array}$ & $\begin{array}{l}\mathrm{W}=1.1 \mathrm{k}_{1} \mathrm{k}_{2} \mathrm{k}_{3}\left\{4 \mathrm{c}+0.7\left(\mathrm{c}_{\mathrm{s}}-\emptyset\right)\right\}\left[\frac{\sigma_{\mathrm{se}}}{\mathrm{E}_{\mathrm{s}}}+\varepsilon^{\prime}{ }_{\mathrm{csd}}\right] \text {; } \\
\mathrm{k}_{2}=\frac{15}{\left(\mathrm{f}^{\prime}{ }^{\prime}+20\right)}+0.7 ; \mathrm{k}_{3}=\frac{5(\mathrm{n}+2)}{7 \mathrm{n}+8} \\
\text { where ' } \mathrm{w} \text { ' is crack width, ' } \mathrm{k}_{1} \text { ' is constant on the surface of rebar, } \\
\text { ' } \mathrm{k}_{2} \text { ' is constant on the concrete quality, ' } \mathrm{f}_{\mathrm{c}} \text { ' is design } \\
\text { compressive strength of concrete, ' } \mathrm{n} \text { ' is number of layers of } \\
\text { tensile rebar, ' } \mathrm{k}_{3} \text { ' is constant to take account of the multiple } \\
\text { layers of tensile bars, ' } \mathrm{c}_{\mathrm{s}} \text { 'is distance of the tensile rebar, ' } \emptyset \text { ' is } \\
\text { diameter of the tensile rebar, ' } \sigma_{\mathrm{se}} \text { ' is tensile stress increment of } \\
\text { the bar, and ' } \varepsilon_{\mathrm{csd}} \text { ' is compressive strain from shrinkage and } \\
\text { creep of concrete. }\end{array}$ & $\begin{array}{l}\text { This model is based on a semi-analytical } \\
\text { approach. The crack spacing model (without } \\
\text { strain components) is based on the concrete cover } \\
\text { and the distance between tensile bars. Bar spacing } \\
\text { has been proved to be a factor for crack spacing } \\
\text { in [83]. The experimental findings in [84] prove } \\
\text { that smooth bars cause large crack spacing. While } \\
\text { both EC } 2 \text { and MC2010 predict increasing crack } \\
\text { width with concrete strength, JSCE code predicts } \\
\text { the opposite. However, this behaviour matches } \\
\text { the results in [66, 85, 86]. Limitations for cover: } \\
\text { No limitations have been mentioned for concrete } \\
\text { cover thickness. }\end{array}$ \\
\hline $\begin{array}{l}\text { ACI } \\
\text { code }[8, \\
24]\end{array}$ & $\begin{array}{l}w=2.2 \beta \varepsilon_{s} \sqrt[3]{d_{c} A} \\
\text { where 'w' is maximum crack width at the extreme tensile fibre } \\
\text { (in), ' } \beta \text { ' is ratio of the distance between the neutral axis and } \\
\text { tension face to the distance between the neutral axis and } \\
\text { centroid of reinforcing steel, ' } \varepsilon_{\mathrm{s}} \text { ' is strain in reinforcement due } \\
\text { to the applied load, ' } \mathrm{d}_{\mathrm{c}} \text { ' is the thickness of the cover from } \\
\text { extreme tension fibre to the closest bar (in), and 'A' is area of } \\
\text { concrete symmetrical with reinforcing steel divided by the } \\
\text { number of bars }\left(\mathrm{in}^{2}\right) \text {. }\end{array}$ & $\begin{array}{l}\text { The empirically based equation was developed in } \\
\text { [49], with the results of six different bending } \\
\text { experiments. The ACI Committee } 224 \text { [24] } \\
\text { modified the aforementioned model by using the } \\
\text { strain, instead of the stress in the reinforcement. } \\
\text { Limitations for concrete cover thickness: No } \\
\text { limitations have been mentioned for concrete } \\
\text { cover. However, the results of specimens with up } \\
\text { to } 84 \text { mm of concrete cover were used to develop } \\
\text { the model. }\end{array}$ \\
\hline $\begin{array}{l}\text { BS code } \\
{[11]}\end{array}$ & $\begin{array}{l}\mathrm{w}=\frac{3 \mathrm{Ce}}{1+2\left(\frac{\mathrm{C}-\mathrm{C} 0}{\mathrm{~d}-\mathrm{d}}\right)}, \quad \text { where } \\
\text { where 'c' is the distance from the point considered to the nearest } \\
\text { bar, 'c } 0 \text { ' is the concrete cover thickness, ' } \mathrm{d} \text { ' is overall depth of } \\
\text { the member, ' } \mathrm{d}_{\mathrm{n}} \text { ' is neutral axis depth calculated on the } \\
\text { assumption that concrete has no tensile strength, ' } \mathrm{d}_{1} \text { ' is } \\
\text { effective depth of a member, ' } \mathrm{b} \text { ' is breadth of the member, 'A } \mathrm{Ast}_{\mathrm{st}} \text { ' } \\
\text { is area of the tensile steel, and 'e } \mathrm{st}_{\mathrm{st}} \text { ' is strain in the steel } \\
\text { assuming concrete has no tensile strength. }\end{array}$ & $\begin{array}{l}\text { The empirically based equation was developed } \\
\text { based on the experiments in [50]. The derived } \\
\text { equation in [50] has been simplified in [87] to be } \\
\text { used in the BS code. Results show that crack } \\
\text { width is linearly proportional for concrete covers } \\
\text { below } 40 \mathrm{~mm} \text {, and the pattern differs when the } \\
\text { cover increases. } \\
\text { Limitations for concrete cover thickness: No } \\
\text { limitations have been mentioned. The results of } \\
\text { specimens with up to } 89 \mathrm{~mm} \text { concrete cover were } \\
\text { used to develop the model. }\end{array}$ \\
\hline
\end{tabular}


Table 2 - Suggested improvements for the EC2 and MC2010 crack-width calculation models

\begin{tabular}{|c|c|c|c|}
\hline Literature & $\begin{array}{l}\text { Improving } \\
\text { Parameter }\end{array}$ & Suggestion & Remarks \\
\hline $\begin{array}{l}\text { Caldentey } \\
(2017)[82]\end{array}$ & $\begin{array}{l}\text { Mean } \\
\text { strain } \\
\text { difference }\end{array}$ & $\begin{array}{l}\text { Include the shrinkage strain effect with a restraint factor } \\
\left(R_{\mathrm{ax}}\right) \text {. } \\
\text { where ' } \mathrm{R}_{\mathrm{ax}} \text { ' can be } 1 \text {, when a member is completely } \\
\text { restrained at edges (e.g., wall is restrained by previously } \\
\text { cast foundation) and ' } \mathrm{R}_{\mathrm{ax}} \text { ' can be } 0 \text {, when restrained at the } \\
\text { ends (e.g. } \mathrm{RC} \text { tie subjected to axial tension). }\end{array}$ & $\begin{array}{l}\text { Investigating the } \\
\text { effect of 'casting } \\
\text { position' [88] from } \\
\text { the experimental } \\
\text { results of }[89,90] \text {. }\end{array}$ \\
\hline \multirow{2}{*}{$\begin{array}{l}\text { Debernardi } \\
\text { and Taliano } \\
(2016)[56] \\
\text { Taliano } \\
(2017)[45]\end{array}$} & $\begin{array}{l}\text { Crack } \\
\text { spacing }\end{array}$ & $\begin{array}{l}\tau_{\text {bms }}=\left(f_{c t} \cdot A_{c}\right) /\left(n_{s} \cdot \pi \cdot \varphi_{s} \cdot L_{s}\right) \text {, where } n_{s} \text { is the number of tensile } \\
\text { bars. } s_{r, m a x}=2 . L_{s}=2 .(1 / 4)\left(f_{c t m} / \tau_{b m s}\right)\left(\emptyset_{s} / \rho_{s, e f}\right) \text {. } \\
\text { Suggest a table of values for the ' } \tau_{b m s} / f_{c t m} \text { ' from the } \\
\text { suggested 'general equation' by Balazs }(1993)[16] .\end{array}$ & \multirow{2}{*}{$\begin{array}{l}\text { According to this } \\
\text { method, cover term } \\
\text { has no influence on } \\
\text { the crack spacing. } \\
\text { Experimental } \\
\text { comparison is made } \\
\text { up to } 45 \mathrm{~mm} \text { of } \\
\text { cover. }\end{array}$} \\
\hline & $\begin{array}{l}\text { Mean } \\
\text { strain } \\
\text { difference }\end{array}$ & $\begin{array}{l}\text { To represent the reduction of tension stiffening, due to } \\
\text { internal cracks, the ' } \mathrm{k}_{\mathrm{t}} \text { ' coefficient is considered as } 0.45 \\
\text { (which is } 0.6 \text { for the short-term load suggested by EC2). } \\
\varepsilon_{\mathrm{sm}}-\varepsilon_{\mathrm{cm}}=\underline{\left.\sigma_{\mathrm{s}}-0.45 \text { (f } \underline{\mathrm{c}}_{\mathrm{ct}, \mathrm{eff}} / \rho_{\mathrm{p}, \mathrm{eff}}\right)\left(1+\alpha_{\mathrm{e}} \rho_{\mathrm{p}, \mathrm{eff}}\right)} \\
\mathrm{E}_{\mathrm{s}}\end{array}$ & \\
\hline $\begin{array}{l}\text { Rospars et al. } \\
(2014)[64] \\
\text { Bisch (2017) } \\
{[65]}\end{array}$ & $\begin{array}{l}\text { Crack } \\
\text { spacing }\end{array}$ & $\begin{array}{l}\text { After a statistical analysis of the results of } 131 \text { tests from } \\
\text { own experiments (CEOS project France) and previous } \\
\text { literature, an equation has been identified } \\
\mathrm{S}_{\mathrm{r}, \max }=1.7\left[1.37 \mathrm{c}+0.117 .\left(\emptyset_{\mathrm{s}} / \rho_{\mathrm{s}, \mathrm{e}}\right)\right]\end{array}$ & $\begin{array}{l}\text { Covers of the } \\
\text { experimental } \\
\text { specimens are } 50 \\
\text { mm and } 70 \mathrm{~mm} \text {. }\end{array}$ \\
\hline
\end{tabular}

The governing parameter of the no-slip theory is concrete cover thickness. The concrete cover thickness influences the surface crack width in two ways [57]: the first is by influencing crack spacing, and the second is by influencing through the effect of shear lag [57]. This shear-lag effect is discussed in several studies in the literature, such as those of Tammo and Thelandersson [53], Beeby et al. [91], and Walraven [92]. A quantitative relationship has been identified for this shear lag in some studies [54, 92]. According to the aforementioned literature, the influence from this shear lag becomes significant when the concrete cover thickness becomes large. Therefore, when improving the existing crack width calculation models to predict the crack widths of large cover cases, the effect of shear lag can be an influencing factor.

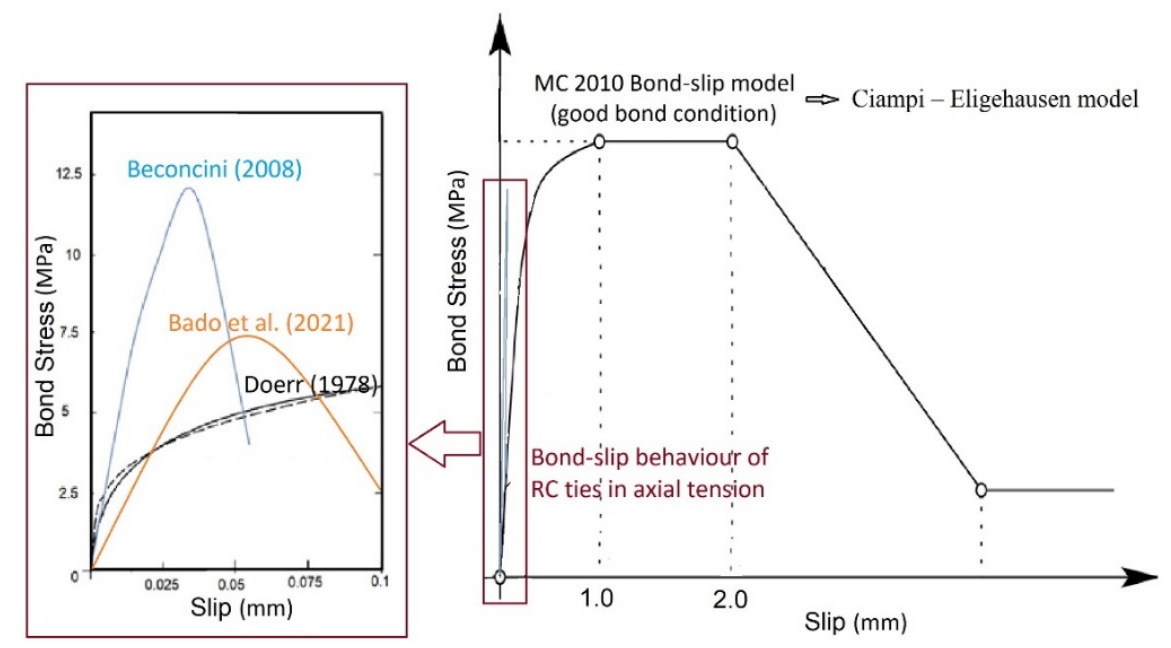

Figure 4. Predicted bond-slip behaviour in MC 2010 and the obtained bond-slip behaviour in axial tensile tests. 


\section{4. COMPARISON OF THE CRACK WIDTH CALCULATION MODEL PREDICTIONS WITH EXPERIMENTAL RESULTS}

Cracking in RC structures has been studied for several decades. Consequently, a large body of experimental studies has been reported in the literature. However, in the recent past, axial tensile tests with multiple bars have become popular in studies of cracking behaviour, since they represent the tensile region of actual cracking behaviour in practical RC members [43, 63]. Therefore, such experimental studies were selected from Gribniak et al. [93], Garcia et al. [90], Dawood and Marzouk [94, 95], Bisch [65], Barre et al. [96] and Tan et al. [27]. Table 3 shows the details of the selected experiments, including the measured maximum crack widths and the predictions according to the aforementioned EC2, MC2010, ACI, JSCE and BS code predictions. As shown in Table 3, the specimens have been listed in ascending order of the concrete cover thickness. The RC specimens have been categorized into three sections, based on concrete cover thickness: Category 1 (15 mm to $39 \mathrm{~mm})$, Category $2(40 \mathrm{~mm}$ to $59 \mathrm{~mm})$ and Category $3(60 \mathrm{~mm}$ to $90 \mathrm{~mm})$. It is important to mention that, in Gribniak et al. [93], the maximum crack width is obtained from the direct readings of the Digital Image Correlation system and, in Dawood and Marzouk [94], the maximum crack width above tensile reinforcement is obtained by multiplying the directly observed maximum crack spacing with a factor of 0.7 , as specified in the same literature. The maximum crack widths mentioned in Tan et al. [27] are the 95 percent fractile of measured crack width at the concrete surface above tensile reinforcement. However, in both Barre et al. [96] and Garcia and Caldentey [90], only the measured average crack width is mentioned. Therefore, in order to obtain the maximum measured crack width, the average value has been multiplied by a factor of 1.7, as specified in Beeby [33].

According to Figure 5, deciding the most suitable crack width prediction model is quite complicated when concrete cover thickness becomes large. When considering the predictions of EC2, except for one case, every other prediction is on the conservative side, and, when the concrete cover increases, the overestimation also increases. Figure 5 and the error values mentioned in Table 3 note this behaviour. When one considers the MC2010 predictions, two cases in Category 3 (Cases 15 and 16) are considerably underestimated. However, it can be seen that MC2010 considers that these two cases are in the crack formation stage, as the steel stress is $200 \mathrm{MPa}$. When considering the predictions of the JSCE code, except for one case, the predictions in Category 3 are on the conservative side. However, for Case 13, the crack width has been significantly overestimated. In both ACI and BS codes, five out of seven cases in Category 3 overestimate the predictions. While considering the predictions of the models, it could be observed that the empirically based ACI and BS codes give relatively best fit for the experimental crack widths. This could be because both ACI and BS models have considered the test results of relatively large cover specimens ( $84 \mathrm{~mm}$ and $89 \mathrm{~mm}$, respectively) while developing the models. However, in considering the predictions of the overall cases and based on the error percentages in Table 3, it is clear that the existing codes need to improve the models for applying RC specimens with large concrete covers.

The aforementioned study has been conducted only for the RC specimens subjected to axial tension. For the specimens subjected to bending, it is important to discuss the effect of curvature on crack width. The empirically based models which are in ACI and BS codes, considered the data from bending tests to develop their models. Furthermore, the model in ACI and BS codes use the ' $\beta$ ' parameter and $\left(d-d_{n}\right) /\left(d_{1}-d_{n}\right)$ factor, respectively to include the effect of curvature. Similarly, MC 2010 recommends multiplying the calculated crack width obtained from the proposed equation with $(h-x) /(d-x)$ ratio to include the curvature effect. Here, ' $h$ ' denotes the total depth of the cross section, ' $d$ ' is the effective depth and ' $\mathrm{x}$ ' is the depth of the neutral axis. Three of these aforementioned factors in ACI, BS and MC 2010 mean the ratio of the distance between the neutral axis and tension face to the distance between the neutral axis and centroid of reinforcing steel. When consider the $\mathrm{RC}$ specimens with large cover thickness, the distance between the neutral axis and tension face becomes relatively larger than the distance between the neutral axis and centroid of reinforcing steel. Therefore, the aforementioned parameters in ACI, BS and 
MC2010 cause to predict large surface crack widths for the specimens with large cover thickness. However, the model in JSCE code does not specifically suggest any method to consider the effect of curvature on crack width. EC2 model considers this effect of curvature would influence to crack spacings. EC2 crack spacing model consist with the ' $\mathrm{k}_{2}$ ' parameter, which cause to predict lower crack spacings for the specimens subjected to bending. The study conducted in Naotunna et al. [43] shows that EC2 model predictions give a good agreement with the experimental results of specimens subjected to bending.

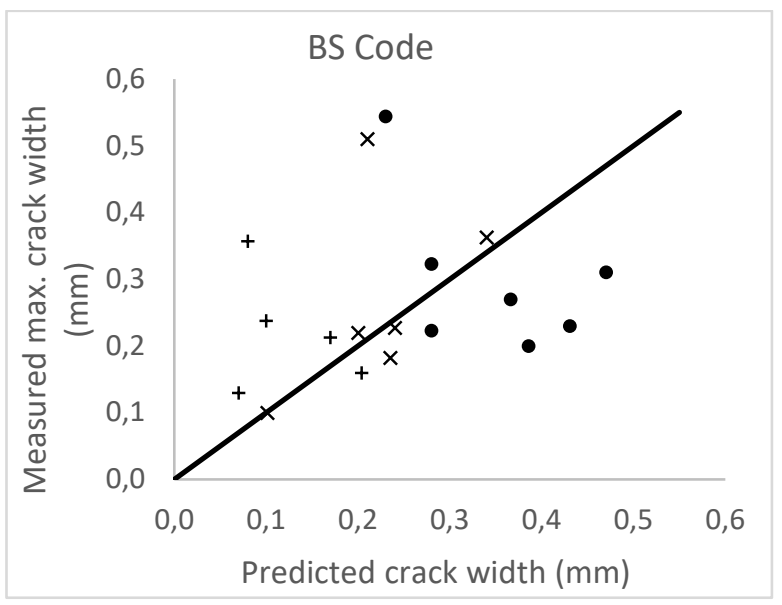

\section{Concrete cover}

$+\quad 15-39 \mathrm{~mm}$

$\times \quad 40-59 \mathrm{~mm}$

- $60-90 \mathrm{~mm}$

Exp. $=$ Predict
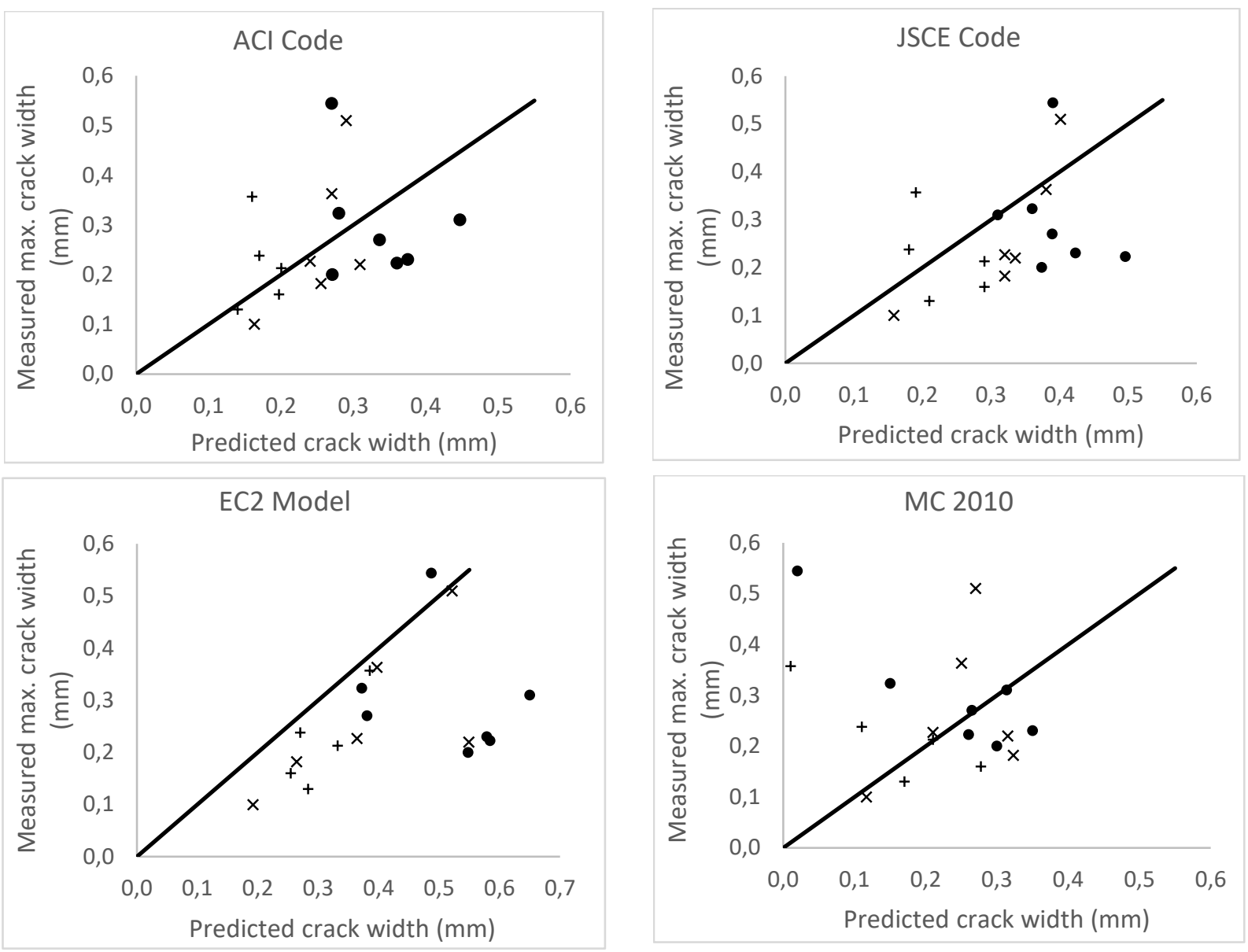

Figure 5 - Predicted versus measured maximum crack widths 
Table 3 - Details of the selected RC specimens with measured and predicted maximum crack widths

\begin{tabular}{|c|c|c|c|c|c|c|c|c|c|c|c|c|c|c|c|c|c|c|}
\hline \multirow[b]{2}{*}{ Case $^{\mathrm{a}}$} & \multirow[b]{2}{*}{ Literature $^{\mathrm{b}}$} & \multirow[b]{2}{*}{$\begin{array}{c}\text { Specimen size } \\
\text { [width } \times \text { height } \times \\
\text { length] }(\mathrm{m})\end{array}$} & \multirow[b]{2}{*}{$\begin{array}{l}\text { Concrete } \\
\text { cover } \\
(\mathrm{mm})\end{array}$} & \multirow[b]{2}{*}{$\begin{array}{l}\text { Steel } \\
\text { stress } \\
(\mathrm{MPa})\end{array}$} & \multirow[b]{2}{*}{$\begin{array}{l}\text { Concrete } \\
\text { strength } \\
(\mathrm{MPa})\end{array}$} & \multirow[b]{2}{*}{$\begin{array}{c}\text { No. } \\
\text { of } \\
\text { bars }\end{array}$} & \multirow[b]{2}{*}{$\begin{array}{l}\text { Bar } \\
\text { dia. } \\
(\mathrm{mm})\end{array}$} & \multirow{2}{*}{$\begin{array}{l}\text { Measure- } \\
\text {-d max } \\
\text { crack } \\
\text { width } \\
(\mathrm{mm})\end{array}$} & \multicolumn{5}{|c|}{ Predicted crack width (mm) } & \multicolumn{5}{|c|}{ Error ${ }^{\mathrm{c}} \%$} \\
\hline & & & & & & & & & త్ & 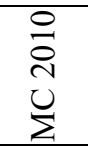 & $\underset{\psi}{己}$ & 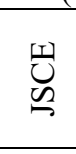 & $\tilde{n}$ & త్ & 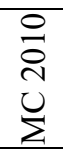 & $\underset{\psi}{\mho}$ & 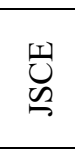 & $\tilde{n}$ \\
\hline 1 & A & $0.15 \times 0.15 \times 1.21$ & 15 & 320 & 42.51 & 4 & 10 & 0.13 & 0.28 & 0.17 & 0.14 & 0.21 & 0.07 & -118 & -31 & -8 & -62 & 46 \\
\hline 2 & A & $0.15 \times 0.15 \times 1.21$ & 30 & 320 & 36.36 & 4 & 10 & 0.21 & 0.33 & 0.21 & 0.20 & 0.29 & 0.17 & -56 & 1 & 6 & -36 & 20 \\
\hline 3 & B & $0.35 \times 0.45 \times 5.22$ & 32 & 200 & 33.77 & 8 & 16 & 0.36 & 0.39 & 0.01 & 0.16 & 0.19 & 0.08 & -8 & 97 & 55 & 47 & 78 \\
\hline 4 & B & $0.35 \times 0.45 \times 5.22$ & 32 & 200 & 41.78 & 8 & 25 & 0.24 & 0.27 & 0.11 & 0.17 & 0.18 & 0.10 & -13 & 54 & 29 & 24 & 58 \\
\hline 5 & $\mathrm{C}$ & $0.9 \times 0.26 \times 010$ & 38 & 333 & 75.00 & 6 & 25 & 0.16 & 0.25 & 0.28 & 0.20 & 0.29 & 0.20 & -59 & -73 & -23 & -81 & -28 \\
\hline 6 & A & $0.15 \times 0.15 \times 1.2$ & 40 & 320 & 42.51 & 4 & 10 & 0.23 & 0.36 & 0.21 & 0.24 & 0.32 & 0.24 & -60 & 7 & -6 & -41 & -6 \\
\hline 7 & $\mathrm{D}$ & $0.4 \times 0.4 \times 2.0$ & 40 & 321 & 74.30 & 8 & 20 & 0.22 & 0.55 & 0.32 & 0.31 & 0.34 & 0.20 & -150 & -43 & -40 & -52 & 9 \\
\hline 8 & $\mathrm{D}$ & $0.4 \times 0.4 \times 2.2$ & 40 & 157 & 74.30 & 8 & 32 & 0.10 & 0.19 & 0.12 & 0.16 & 0.16 & 0.10 & -92 & -17 & -63 & -58 & -1 \\
\hline 9 & $\mathrm{C}$ & $0.9 \times 0.38 \times 0.10$ & 45 & 333 & 65.00 & 6 & 30 & 0.18 & 0.26 & 0.32 & 0.26 & 0.32 & 0.24 & -45 & -77 & -40 & -76 & -29 \\
\hline 10 & $\mathrm{E}$ & $0.355 \times 0.355 \times 3.5$ & 45 & 300 & 40.00 & 8 & 16 & 0.51 & 0.52 & 0.27 & 0.29 & 0.40 & 0.21 & -2 & 47 & 43 & 21 & 59 \\
\hline 11 & A & $0.15 \times 0.15 \times 1.24$ & 50 & 320 & 36.44 & 4 & 10 & 0.36 & 0.40 & 0.25 & 0.27 & 0.38 & 0.34 & -9 & 31 & 26 & -5 & 6 \\
\hline 12 & $\mathrm{C}$ & $0.9 \times 0.26 \times 0.9$ & 63 & 333 & 75.00 & 6 & 25 & 0.20 & 0.55 & 0.30 & 0.27 & 0.37 & 0.39 & -174 & -50 & -36 & -87 & -93 \\
\hline 13 & E & $0.355 \times 0.355 \times 3.6$ & 65 & 254 & 46.30 & 4 & 25 & 0.22 & 0.58 & 0.26 & 0.36 & 0.50 & 0.28 & -162 & -17 & -62 & -123 & -26 \\
\hline 14 & $\mathrm{C}$ & $0.9 \times 0.38 \times 0.9$ & 75 & 333 & 65.00 & 6 & 30 & 0.23 & 0.58 & 0.35 & 0.38 & 0.42 & 0.43 & -152 & -52 & -63 & -84 & -87 \\
\hline 15 & B & $0.35 \times 0.45 \times 5.22$ & 82 & 200 & 32.91 & 8 & 16 & 0.54 & 0.49 & 0.02 & 0.27 & 0.39 & 0.23 & 10 & 96 & 50 & 28 & 58 \\
\hline 16 & B & $0.35 \times 0.45 \times 5.22$ & 82 & 200 & 44.39 & 8 & 25 & 0.32 & 0.37 & 0.15 & 0.28 & 0.36 & 0.28 & -15 & 54 & 13 & -11 & 13 \\
\hline 17 & $\mathrm{D}$ & $0.4 \times 0.4 \times 2.1$ & 90 & 293 & 74.30 & 8 & 20 & 0.31 & 0.65 & 0.31 & 0.45 & 0.31 & 0.47 & -110 & -1 & -44 & 0 & -52 \\
\hline 18 & $\mathrm{D}$ & $0.4 \times 0.4 \times 2.3$ & 90 & 212 & 74.30 & 8 & 32 & 0.27 & 0.38 & 0.26 & 0.34 & 0.39 & 0.37 & -41 & 2 & -24 & -44 & -36 \\
\hline \multicolumn{19}{|c|}{$\begin{array}{l}\text { Notes. } \\
\text { The specimens have been arranged in ascending order, based on cover thickness } \\
\text { a Cases } 1 \text { to } 5 \text { - Category } 1 \text {, Cases } 6 \text { to } 11 \text { - Category } 2 \text {, Cases } 12 \text { to } 18-\text { Category } 3 \\
{ }^{b} \text { Gribniak et al. (2020) - A, Garcia et al. (2020) - B, Dawood et al. (2011) - C, Tan et al. (2018) - D, Barre et al. (2016) - E } \\
{ }^{c} \text { Error = (experimental value - predicted value)/experimental value. }\end{array}$} \\
\hline
\end{tabular}


It is clear that the surface crack width increases with the increase in concrete cover thickness (Sections 3 and 4). When considering the allowable crack width limits in the discussed codes, with the exception of the JSCE code, every other code's allowable limit does not increase with the concrete cover thickness. The allowable crack width limits of an RC structure (in the absence of a water tightness requirement) have been decided for durability and aesthetic acceptance.

It can be observed that the prescribed allowable crack width limits in the codes have been changed from time to time. For example, Model Code 1978 [9] and MC 90 [5] recommend $0.1 \mathrm{~mm}$ and $0.3 \mathrm{~mm}$ crack widths, respectively, for severe exposure classes. Further, the allowable limits in each code differ from each other. For structures exposed to adverse environmental conditions, EC2, MC2010 and BS codes recommend limiting the crack widths to $0.3 \mathrm{~mm}$ (Table 7.1 N in EC2, Cl. 7.6.4.1.4 in MC2010 and Cl. 3.2.4 in BS codes). The allowable crack width limit of the JSCE code is shown in Table 4. Moreover, for severe exposure conditions, the ACI 318 code recommends limiting the crack width to $0.33 \mathrm{~mm}(\mathrm{Cl}$. 10.6.4), while the ACI 224 report recommends limiting it to $0.15 \mathrm{~mm}$ (Table 4.1 in ACI 224R [24]). However, the Norwegian National Annex [97] follows slightly different criteria than EC2. It has introduced a $\mathrm{k}_{\mathrm{c}}$ coefficient $\left(\mathrm{k}_{\mathrm{c}}=\mathrm{c}_{\text {nom }} / \mathrm{c}_{\text {min,dur }} \leq 1.3\right)$ and allows the EC2-specified crack width limit to be multiplied by the $\mathrm{k}_{\mathrm{c}}$ coefficient.

To compare the applicability of allowable crack width limits, the discussed experimental results in Table 3 have been considered. According to the ACI code [8], the limitation of the steel stress at the serviceability limit state is considered as $2 / 3$ of the yield strength of the reinforcement. Therefore, to match this requirement, Cases 1, 2 and 4 from Category 1, Cases 7, 9, and 11 from Category 2 and Cases 12, 14 and 17 from Category 3 have been selected. The steel stress in these selected cases lies within 293 MPa to 333 MPa. The experimental crack widths of these selected cases have been compared with the allowable crack width limits of the aforementioned codes, as shown in Figure 6. The selected allowable limits in Figure 6 are for the adverse/corrosive environmental conditions. Considering the limitation according to the ACI 224 code, only the case with $15 \mathrm{~mm}$ concrete cover thickness satisfies the criterion. The EC2, MC2010 and BS codes have a similar limit for the allowable crack width $(0.3 \mathrm{~mm})$ for specimens in adverse environmental conditions. Except for the two cases with $50 \mathrm{~mm}$ and $90 \mathrm{~mm}$ concrete cover thickness, other cases satisfy this guideline. When considering the ACI 318 limit, which is $0.33 \mathrm{~mm}$, only one case, with a $50 \mathrm{~mm}$ cover, shown in Table 4 does not satisfy the criteria. When considering the JSCE guideline, which is shown in Table 4, all the cases in Category 3 satisfy this criterion, but the cases in Category 1 and 2 do not satisfy it.

Therefore, in order to identify the most suitable allowable crack width limit, it is important to investigate the reasons for the aforementioned differences in each code. Further, to discover the effect of concrete cover thickness on the allowable crack width, an extensive literature survey has been carried out. The focus is to identify how the existing limits are placed and to check whether the increased crack width of specimens with an increase in concrete cover has an effect on the durability and the aesthetic aspect of an $\mathrm{RC}$ structure.

Table 4 - The limit value of crack width as per JSCE standards (Table 8.3.2 in JSCE standard)

\begin{tabular}{|l|l|l|l|}
\hline & \multicolumn{3}{|c|}{ Environmental condition } \\
\cline { 2 - 4 } & Normal & Corrosive & Severely corrosive \\
\hline Deformed bars and plain bars & $0.005 \mathrm{c}$ & $0.004 \mathrm{c}$ & $0.0035 \mathrm{c}$ \\
\hline Note - ' $\mathrm{c}$ ' is concrete cover thickness \\
\hline
\end{tabular}




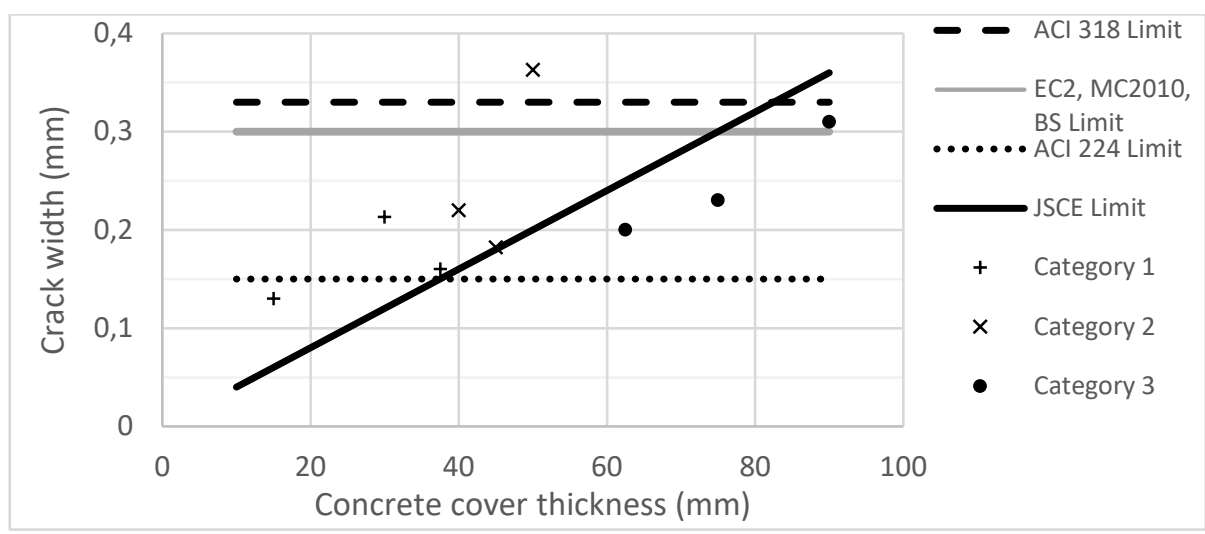

Figure 6 - Experimental crack widths of the selected specimens from Categories 1, 2 and 3 (Table 3) and the allowable crack width limits of different codes in adverse environmental conditions

\section{CRACK WIDTH LIMITATION CONSIDERING THE DURABILITY}

There is consensus that cracks appearing in reinforced concrete structures lead to the penetration of $\mathrm{CO}_{2}$, chloride, corrosive agents and water to the reinforcement and can initiate reinforcement corrosion [3, 98]. Reinforcement corrosion could lead to a reduction in the amount of steel in the reinforcement and the corrosive products expanding in volume. To reduce the adverse effect of cracking, the current practice is to limit the width of the crack. Further, increasing the concrete cover is one of the main measures that has been identified to enhance the durability of an RC structure. However, as per the previous discussion, the crack width also increases with the simultaneous increase in concrete cover. This reveals that the discussed actions considered to increase durability contradict one another. Therefore, in order to identify how the existing allowable crack width limits are decided, based on durability, a literature survey has been carried out.

\subsection{Previous studies on crack width and reinforcement corrosion}

In the available literature, various types of experiments that have studied the effect of crack width on reinforcement corrosion can be identified. However, when considering the results of some of these experiments, the effect of crack width on reinforcement corrosion is quite complicated. Depending on the experimental duration and the outcome of the results of the available experiments, the authors have divided them into four categories: 1 . the 'crack width' does not have a 'relatively short-term' effect on corrosion; 2. the 'crack width' has a 'relatively short-term' effect on corrosion; 3. the 'crack width' does not have a 'long-term' effect on corrosion; and 4. the 'crack width' has a 'long-term' effect on corrosion, as given in Table 5. Experiments conducted for up to 10 years are categorized as 'relatively short-term' experiments; those which have continued for longer, or experiments conducted for more than 10 years, are considered 'long-term experiments'.

When considering the experiments of Category 1, the conclusion is that the cracks cause the initiation of corrosion, regardless of crack width. The studies in this category have observed a similar amount of corrosion in locations with different crack widths. However, it is important to identify that most of the experiments categorized in Category 1 had released the load during exposure. Therefore, even where the surface crack width remains open, there is a possibility of closing the internal crack. This could be a reason why a similar amount of corrosion is observed at cracks with different surface crack widths. The experiment in Category 4 concludes that the crack width has an effect on long-term corrosion. However, the specimens tested in the experiment used air-entrained concrete, and only 11 specimens out of 82 were 
able to be tested, due to excessive damage. It is quite impossible to explain the damage to this number of mentioned specimens within 25 years (service life), with the conventional method of corrosion.

Table 5 - The details and the outcome of previous experiments on crack width and corrosion

\begin{tabular}{|c|c|c|c|c|c|c|c|c|}
\hline \multirow{2}{*}{ 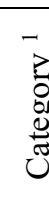 } & \multirow[b]{2}{*}{ 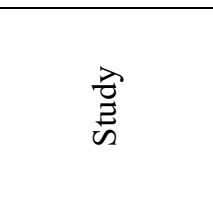 } & \multicolumn{5}{|c|}{ Experiment Details } & \multirow[b]{2}{*}{$\begin{array}{l}\stackrel{n}{ت} \\
\stackrel{\overrightarrow{0}}{0} \\
\stackrel{0}{4}\end{array}$} & \multirow[b]{2}{*}{ 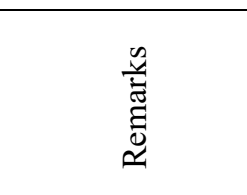 } \\
\hline & & 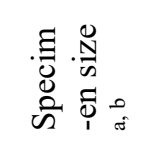 & 它 & 总吾 & 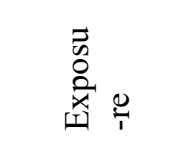 & 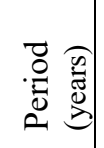 & & \\
\hline \multirow[t]{7}{*}{1} & $\begin{array}{l}\text { Makita et al. } \\
\text { [99] }\end{array}$ & $\begin{array}{l}\text { Length } \\
750\end{array}$ & & $0.05-0.3$ & Seawater & 2.7 & \multirow{2}{*}{$\begin{array}{l}\text { Corrosion does not } \\
\text { relate to crack width }\end{array}$} & \multirow{2}{*}{$\begin{array}{l}\text { Specimens were } \\
\text { unloaded during } \\
\text { exposure. }\end{array}$} \\
\hline & $\begin{array}{l}\text { Berke et al. } \\
{[100]}\end{array}$ & $\begin{array}{l}762 \times \\
152 \times 152\end{array}$ & 38 & $\begin{array}{l}0.2 \\
(\text { mean) }\end{array}$ & $\begin{array}{l}\mathrm{NaCl} \\
\text { solution }\end{array}$ & 1.3 & & \\
\hline & $\operatorname{Lin}[101]$ & $\begin{array}{l}914 \times 76 \times \\
152\end{array}$ & & $\begin{array}{l}0.1 \\
0.15 \\
0.18 \\
\end{array}$ & Seawater & $\begin{array}{l}2 \\
10\end{array}$ & $\begin{array}{l}\text { Corrosion does not } \\
\text { relate to crack width }\end{array}$ & $\begin{array}{l}\text { Specimens were } \\
\text { loaded during } \\
\text { exposure. }\end{array}$ \\
\hline & $\begin{array}{l}\text { Tremper } \\
{[102]}\end{array}$ & $\begin{array}{l}200 \times \\
200 \times 63\end{array}$ & 28 & $\begin{array}{l}0.127- \\
0.508\end{array}$ & $\begin{array}{l}\text { Coastal } \\
\text { exposure }\end{array}$ & 10 & $\begin{array}{l}\text { Corrosion only in } \\
\text { cracked locations. }\end{array}$ & $\begin{array}{l}\text { Specimens were } \\
\text { unloaded. }\end{array}$ \\
\hline & $\begin{array}{l}\text { Francois et al. } \\
{[103]}\end{array}$ & $\begin{array}{l}3000 \times \\
150 \times 280\end{array}$ & & $<0.5$ & $\begin{array}{l}\mathrm{NaCl} \& \\
\mathrm{CO}_{2} \text { prone }\end{array}$ & 10 & $\begin{array}{l}\text { No relationship to } \\
\text { crack width. }\end{array}$ & \\
\hline & $\begin{array}{l}\text { Kahhaleh } \\
{[104]}\end{array}$ & & 50 & $\begin{array}{l}\text { Around } \\
0.33\end{array}$ & $\begin{array}{l}\mathrm{NaCl} \\
\text { solution }\end{array}$ & 1.1 & $\begin{array}{l}\text { Corrosion does not } \\
\text { relate to crack width }\end{array}$ & $\begin{array}{l}\text { Both loaded and } \\
\text { unloaded. }\end{array}$ \\
\hline & \begin{tabular}{|l}
$\begin{array}{l}\text { Chen et al. } \\
{[105]}\end{array}$ \\
\end{tabular} & $\begin{array}{l}1100 \times \\
180 \times 100\end{array}$ & 30 & $0.1-0.4$ & $\begin{array}{l}\mathrm{NaCl} \\
\text { solution }\end{array}$ & 3 & $\begin{array}{l}\text { Corrosion does not } \\
\text { relate to crack width }\end{array}$ & $\begin{array}{l}\text { Cracks induce } \\
\text { corrosion }\end{array}$ \\
\hline \multirow[t]{10}{*}{2} & $\begin{array}{l}\text { Ohta (i) } \\
{[106]}\end{array}$ & $\begin{array}{l}1000 \times \\
150 \times 150\end{array}$ & $\begin{array}{l}20 \\
40\end{array}$ & $\begin{array}{l}0-0.1 \\
0.1-0.2 \\
0.2-0.3\end{array}$ & Coastal & 10 & $\begin{array}{l}20 \mathrm{~mm} \text { cover, every } \\
\text { cracked location is } \\
\text { similarly corroded. }\end{array}$ & $\begin{array}{l}40 \mathrm{~mm} \text { cover, } \\
\text { corrosion relates } \\
\text { to crack width. }\end{array}$ \\
\hline & \begin{tabular}{|ll} 
Schiessl & (i) \\
{$[25,107]$} & \\
\end{tabular} & $\begin{array}{l}1950 \times \\
250 \times 150 \\
\end{array}$ & $\begin{array}{l}25 \\
35 \\
\end{array}$ & $\begin{array}{l}0.075- \\
0.55 \\
\end{array}$ & Mixed & 4 & $\begin{array}{l}\text { Corrosion and crack } \\
\text { width are related. }\end{array}$ & \\
\hline & $\begin{array}{l}\text { Carevic and } \\
\text { Ignjatovic } \\
{[108]}\end{array}$ & $\begin{array}{l}500 \times \\
100 \times 100\end{array}$ & 25 & $0.05-0.3$ & $\begin{array}{ll}2 \% & \mathrm{CO}_{2} \\
\text { with } & 65 \% \\
\text { humidity }\end{array}$ & 0.1 & $\begin{array}{l}\text { Corrosion is } 3 \text { times } \\
\text { higher in } 0.3 \mathrm{~mm} \\
\text { cracked locations. }\end{array}$ & \\
\hline & $\begin{array}{l}\text { Schiessl and } \\
\text { Raupach } \\
\text { [109] } \\
\end{array}$ & $\begin{array}{l}700 \times 97 \times \\
150\end{array}$ & 15 & $0.1-0.5$ & Saltwater & 2 & $\begin{array}{l}\text { Corrosion increases } \\
\text { with increasing } \\
\text { crack width. }\end{array}$ & \\
\hline & Swamy [110] & $\begin{array}{l}\text { Length } \\
760\end{array}$ & $\begin{array}{l}50 \\
70\end{array}$ & $0.11-0.25$ & Marine & & $\begin{array}{l}\text { Corrosion above } \\
0.15 \mathrm{~mm} \text { cracks. }\end{array}$ & \\
\hline & \begin{tabular}{|l} 
Misra et al. \\
{$[111]$}
\end{tabular} & \begin{tabular}{|l|}
$2100 \times$ \\
$100 \times 200$ \\
\end{tabular} & 10 & & Marine & 1 & \multirow{2}{*}{$\begin{array}{l}\text { Crack width above } \\
0.5 \mathrm{~mm} \text { shows } \\
\text { severe corrosion. }\end{array}$} & \\
\hline & $\begin{array}{l}\text { Vennesland } \\
\text { et al. [112] }\end{array}$ & \begin{tabular}{|l|}
$500 \times$ \\
$100 \times 100$ \\
\end{tabular} & & $0.1-2.0$ & Seawater & 0.3 & & \\
\hline & \begin{tabular}{|l} 
Miyagawa \\
{$[113]$}
\end{tabular} & $\begin{array}{l}1000 \times \\
50 \times 50 \\
\end{array}$ & 20 & $<0.3$ & $\begin{array}{l}\mathrm{NaCl} \\
\text { solution }\end{array}$ & & $\begin{array}{l}\text { Corrosion above } 0.2 \\
\text { mm cracks. }\end{array}$ & \\
\hline & Li et al. [114] & \begin{tabular}{|l|}
$400 \times$ \\
$100 \times 100$ \\
\end{tabular} & 40 & $0-0.5$ & $\begin{array}{l}\mathrm{NaCl} \\
\text { solution }\end{array}$ & 1.8 & $\begin{array}{l}\text { Corrosion and crack } \\
\text { width are related } \\
\end{array}$ & $\begin{array}{l}\text { Plain bars were } \\
\text { used. }\end{array}$ \\
\hline & $\begin{array}{l}\text { Houston et al. } \\
{[115]}\end{array}$ & & $\begin{array}{l}25 \\
50 \\
75 \\
\end{array}$ & & $\begin{array}{l}\mathrm{NaCl} \\
\text { solution }\end{array}$ & 2.8 & $\begin{array}{l}50 / 75 \mathrm{~mm} \text { covers, } \\
\text { corrosion above } \\
0.13 \mathrm{~mm} \text { cracks }\end{array}$ & $\begin{array}{l}25 \mathrm{~mm} \text { cover, } \\
\text { corrosion in } \\
\text { every location. }\end{array}$ \\
\hline \multirow[t]{2}{*}{3} & $\begin{array}{l}\text { Ohta et al. } \\
{[106]}\end{array}$ & $\begin{array}{l}1000 \times \\
150 \times 150\end{array}$ & $\begin{array}{l}20 \\
40\end{array}$ & $\begin{array}{l}0-0.1 \\
0.1-0.2 \\
0.2-0.3 \\
\end{array}$ & Coastal & 20 & \multirow{2}{*}{$\begin{array}{l}\text { Corrosion and crack } \\
\text { width are not } \\
\text { related. }\end{array}$} & \multirow{2}{*}{$\begin{array}{l}\text { Every cracked } \\
\text { location is } \\
\text { similarly } \\
\text { corroded. }\end{array}$} \\
\hline & $\begin{array}{ll}\text { Schiessl (ii) } \\
{[25,107]}\end{array}$ & $\begin{array}{l}1950 \times \\
250 \times 150 \\
\end{array}$ & $\begin{array}{l}25 \\
35 \\
\end{array}$ & $\begin{array}{l}0.075- \\
0.55 \\
\end{array}$ & Mixed & 10 & & \\
\hline 4 & O’Neil [116] & & 19 & $\begin{array}{l}0-0.4 \\
\text { Above } \\
0.4\end{array}$ & $\begin{array}{l}\text { Tidal wave } \\
\text { with freeze } \\
\text { and thaw }\end{array}$ & 25 & $\begin{array}{l}\text { Corrosion above } 0.4 \\
\text { mm cracks. } 11 / 82 \\
\text { specimens tested. }\end{array}$ & $\begin{array}{l}\text { air-entrained } \\
\text { concrete. }\end{array}$ \\
\hline
\end{tabular}


1. Crack width has no effect on corrosion (relatively short-term), 2. Crack width has an effect on corrosion (relatively short-term), 3. Crack width has no effect on corrosion (long-term), 4. Crack width has an effect on corrosion (long-term)

By observing Categories 2 and 3, it can be concluded that the corrosion initiation takes place at cracks and, at this stage, the 'crack width' plays a vital role. However, when the testing time increases, the crack width does not influence corrosion. This could be the main reason why MC 1978 prescribes limiting the crack width in severe conditions to $0.1 \mathrm{~mm}$ and releases it in MC 90 and MC2010 to $0.3 \mathrm{~mm}$. It can be assumed that MC 1978 had considered the short-term tests, and this limitation was changed after considering the results of long-term experiments. The two main causes for reinforcement corrosion are chloride-induced damage and carbonation [117]. When the Chloride ions in the surrounding environment reach to the reinforcement, that cause to damage the protective layer around the reinforcement. The carbonation means the change in the alkaline $\mathrm{pH}$ of concrete to neutral $\mathrm{pH}$ [118]. This mainly happens when the atmospheric Carbon Dioxide penetrate into concrete and react with the Calcium Hydrate in concrete. This reaction cause to increase the Calcium Carbonate fraction in concrete which cause to neutralize the $\mathrm{pH}$ value. The protective layer around the reinforcement gets damaged within the neutralized $\mathrm{pH}$ environment and this cause to initiate corrosion. When there are cracks in concrete, the time required to penetrate the carbonation or chloride layer to the rebar is drastically reduced, and corrosion can be initiated in the early stages [3]. At this stage, as per the findings in Category 2, corrosion can be proportional to the crack width. However, in long-term, the penetration depth will reach to the reinforcement. Then, as per the findings in Category 3 , after the penetration depth reach to the reinforcement, there is no difference in the amount of corrosion in locations with small crack widths and large crack widths or in uncracked locations.

\subsection{Deciding the allowable crack width limits on durability for structures with different concrete covers}

Schiessl's experiment mentioned in the report in [107] has been considered by many researchers in the field; it tried to elaborate criteria for limiting the value of crack width. In the mentioned study, the level of corrosion in the reinforcement is categorized, based on the measured corrosion height ( ' $\mathrm{t}_{\mathrm{m}}$ ' - based on the prepared 'rust calibration scale' by the author in [107]), as 'passive corrosion' ( $\left.\mathrm{t}_{\mathrm{m}}<0.01 \mathrm{~mm}\right)$ or 'active corrosion' ( $\mathrm{t}_{\mathrm{m}}>0.01 \mathrm{~mm}$ ). For specimens exposed for four years, active corrosion could be observed from crack widths of $0.125 \mathrm{~mm}$ onwards. Further, this study tried to emphasize the possibility of increasing the limit of allowable crack width, with the increase in concrete cover. For specimens exposed for 10 years, active corrosion could be observed, even at uncracked locations. However, Schiessl identified that, when the concrete cover is $25 \mathrm{~mm}, 66 \%$ of cracks are active in corrosion when the crack width is $0.3 \mathrm{~mm}$. When the concrete cover is increased to $35 \mathrm{~mm}$, only $50 \%$ of cracks are shown to be active in corrosion for a 0.3 $\mathrm{mm}$ crack width. Based on the results of this long-term experiment, it can be stated that increasing the concrete cover has the potential to increase the limit of allowable crack width. Therefore, this study can be further improved for RC specimens with increased concrete cover thickness and develop an allowable crack width limit which is dependent on concrete cover thickness.

\section{CRACK WIDTH LIMITS CONSIDERING THE AESTHETIC ASPECT}

Each code of practice has specified the allowable crack width limits, based on the structure's exposure class. When deciding this allowable limit for the structure's built-in environmental conditions, where there is no risk of corrosion, the limits are given in consideration of the aesthetic acceptance of the structure. Although, RC structures are designed and constructed by experts in the field, they are used by ordinary citizens, who do not have any expertise or knowledge in the field. Therefore, users should always feel that 
it is safe to use them. It is obvious that unsatisfactory appearance, due to cracks, causes safety alarms and lowers the acceptance of a structure [119]. However, the aesthetic acceptance of cracks in RC structures is one of the research areas, which have attracted the least attention [120]. Leonhardt [1] stated that, if the structure has a reasonable cover thickness with good quality concrete, a crack width of $0.4 \mathrm{~mm}$ is not harmful to its durability (corresponding with the outcome of O'Neil [116]), but in order to avoid unnecessary concern among casual observers, the crack width should be limited to $0.2 \mathrm{~mm}$. However, it is not possible to state a fixed value for all types of RC structures and for every type of user, as the viewer's attitude can have a greater influence than what is actually observed [121]. On the other hand, it is not possible to limit the widths of controllable cracks to a fine level, as this would increase the cost of the structure. In order to justify the statement that the user's attitude is of greater influence than the actual effect of the cracks, the study performed by Padilla and Robles [122] gives good agreement. The study was based on cracks in a low-cost housing scheme and clearly emphasized how the different sizes of crack widths affected tenants, landlords or engineers. Figure 7 illustrates different observers' attitudes towards a crack and the actual effect of a crack on a structure. According to this figure, when the time has come for actual concern about the cracks, the users of the structure have already abandoned it.

\subsection{The allowable crack width limits on the aesthetic acceptance of structures with different concrete covers}

The concrete cover thickness is decided on to protect the reinforcement against corrosion, for the safe transmission of bond forces and for adequate fire resistance [7]. Therefore, even for structures that are not threatened by corrosion, large covers can be decided on, due to the safe transmission of bond forces and for adequate fire resistance. As mentioned in the introduction, according to EC2, for the safe transmission of bond forces, concrete covers can be large as $56 \mathrm{~mm}$ for cases with bundled bars. The surface crack width increases with the increase in concrete cover thickness. The limit of visibility of cracks is expressed by 'crack width' [1,119], and a proper guide should be available to the client to decide the allowable crack widths. The study conducted by Campbell-Allen, mentioned in the report in [119], identified that the minimum crack width of a structure is a function of viewing distance, a structure's prestige and the nature of the surface (the visibility of cracks changes when they are wet or filled with impurities). The authors proposed several categories of structures, depending on their prestige, and graphically interpreted the acceptable crack widths, depending on the distance of the viewer. Figure 8 shows the proposed criterion and, as it shows for the high-prestige structures, even for longer viewing distances, the allowable crack width limits have to be limited to a relatively low level.

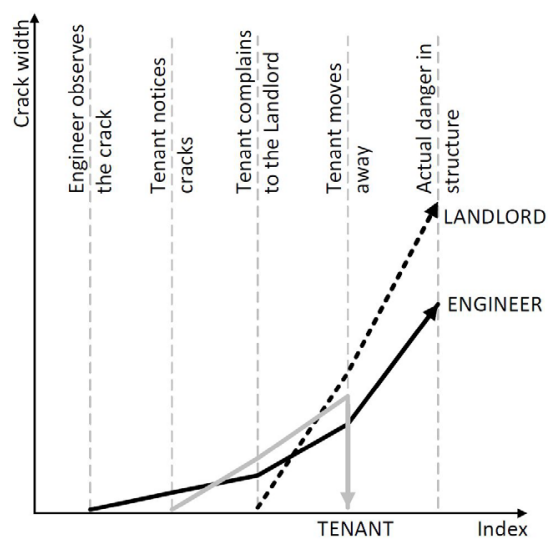

Figure 7 - Different observers' attitudes to a crack (adapted from Padilla and Robles 1971)

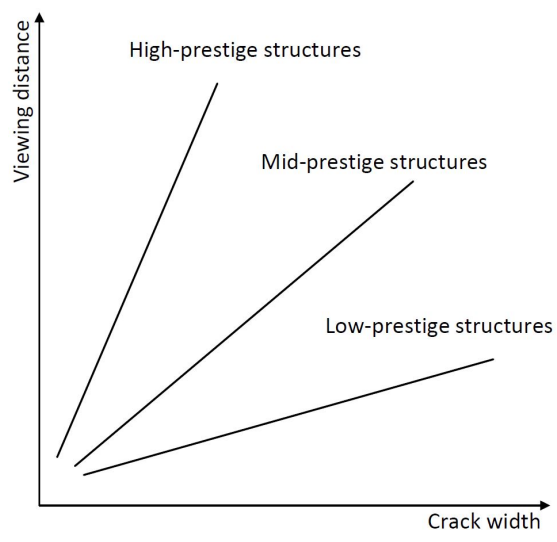

Figure 8 - Aesthetically acceptable crack width (adapted from Campbell-Allen 1979) 
The outcomes of the aforementioned study by Campbell-Allen [119] can be extended for every type of structure and used to estimate the allowable maximum crack width in respect of the aesthetic aspect. Every structure (or part of the structure) can be categorized into different prestige levels, depending on its usage (purpose of the structure and number of users). For example, monumental structures, pedestrian bridges, etc. can be categorized as 'higher prestige level' and structures like dams, highway bridges and storage buildings can be categorized as structures with a 'lower prestige level'. Then, the client can identify the category of the structure and the average viewing distance, to measure the allowable crack width limit as per aesthetic satisfaction. It can be concluded that, for structures categorized at the higher prestige level, the increasing concrete cover thickness causes a comparatively higher amount of tensile reinforcement to be required, to limit the crack width. Therefore, for such cases, the use of bundled bars, etc. have to be reconsidered at the structural design stage.

SUMMARY AND CONCLUSIONS

The background of the widely used crack width calculation models has been discussed, starting with the complex cracking phenomenon. Empirically based crack width calculation models in ACI and BS codes and the semi-analytical models in EC2, MC2010 and JSCE codes have been examined. The crack width governing parameters in the aforementioned models have been categorized, and the extensive background study of each model led to deciding on suitable models for cases with large concrete cover thickness. Then, the necessity of considering the shear-lag effect (which is reported in several studies), identifying the proper bond-slip behaviour, has been highlighted in this paper. Based on a study comparing the experimental results with the model predictions in Section 4, it has been identified that the EC2 model predictions are more conservative, and both ACI and BS code model predictions gave a good agreement with the experimental crack widths of the specimens with concrete cover thickness above $60 \mathrm{~mm}$.

It can be seen that the allowable crack width limits in the aforementioned codes of practice have changed from time to time and differ from each other. Therefore, an extensive literature survey has been conducted to investigate the background of the allowable crack width limits. According to the durability aspect, the allowable crack width limits can be identified as increasing with the concrete cover thickness, as in the JSCE code. This is based on the long-term study conducted by Schiessl (1975). However, this study was conducted for specimens with $25 \mathrm{~mm}$ and $35 \mathrm{~mm}$ cover thicknesses. The same study can be extended for specimens with different cover thicknesses, to identify the allowable crack width limits for cases with different concrete cover thicknesses.

Concrete cover thickness is decided based on durability, safe transmission of bond forces and for fire resistance. According to the EC2 model, to provide the safe transmission of bond forces, the cover thickness can be up to $55 \mathrm{~mm}$. Therefore, even for structures which are not built-in severe exposure classes, the cover thickness can be large. The allowable crack width limits of such structures are mainly based on the aesthetic appearance. In order to control the crack widths of such structures effectively, the authors suggest using the study conducted by Campbell-Allen (1979) and deciding the allowable limit based on the structure's prestige level (the purpose and number of users of the structure). Finally, this study has identified and highlighted the necessary improvements in the existing crack controlling methods, to effectively control the cracks of structures with large concrete covers.

\section{REFERENCES}

1. Leonhardt F: "Cracks and crack control in concrete structures". PCI Journal, Vol. 33, No. 4, 1988, pp. 124-145. 
2. Makhlouf H M \& Malhas F A: "The effect of thick concrete cover on the maximum flexural crack width under service load". Structural Journal, Vol. 93, No. 3, 1996, pp. 257-265.

3. Beeby A: "Concrete in the oceans technical report no. 1". Cement and Concrete Association, Slough, UK, No., 1978.

4. JSCE: "Standard specifications for concrete structures-2007 “design"”. JSCE Guidelines for Concrete", 2007.

5. CEB-FIP: "90. Design of concrete structures. Ceb-fip-model-code 1990". British Standard Institution, London, 1993.

6. fib: "Fib model code for concrete structures", Structural Concrete, 2010.

7. CEN: "EN 1992-1-1 Eurocode 2: Design of concrete structures - part 1-1: General rules and rules for buildings", 2004.

8. ACI: "Building code requirements for structural concrete:(ACI 318-95); and commentary (aci 318r95)", 1995.

9. Model Code: "Ceb-fip model code for concrete structures", Comité Euro-International du Béton, Paris, France; 1978.

10. BS Institute: "EN 1991-1-1 eurocode 2: Design of concrete structures, general rules and rules for buildings." UK, 1992.

11. BS: "8110: Part 1, structural use of concrete-code of practice for design and construction", 1985.

12. Gergely P \& Lutz L A: "Maximum crack width in reinforced concrete flexural members". ACI Special Publication, Vol. 20, No., 1968, pp. 87-117.

13. Kaar P H \& Hognestad E: "High strength bars as concrete reinforcement, part 7: Control of cracking in t-beam flanges": Portland Cement Association, Research and Development Laboratories; 1965.

14. Sygula S: "Vergleichende untersuchungen über biegerißformeln für stahlbeton". Beton-und Stahlbetonbau, Vol. 76, No. 5, 1981, pp. 114-117.

15. AIJ: "Aij: Standard for structural calculation of rc structures", Tokyo, 1986.

16. Balazs G L: "Cracking analysis based on slip and bond stresses". Materials Journal, Vol. 90, No. 4, 1993, pp. 340-348.

17. Tan R, Hendriks M A, Geiker M \& Kanstad T: "Modified cracked membrane model for consistent crack width predictions of reinforced concrete structures subjected to in-plane loading". Engineering Structures, Vol. 196, No., 2019, pp. 109362.

18. Oh B H \& Kang Y J: "New formulas for maximum crack width and crack spacing in reinforced concrete flexural members". Structural Journal, Vol. 84, No. 2, 1987, pp. 103-112.

19. Markeset G \& Kioumarsi M: "Need for further development in service life modelling of concrete structures in chloride environment". Procedia Engineering, Vol. 171, No., 2017, pp. 549-556.

20. Connal J \& Berndt M: "Sustainable bridges: 300 year design life for second gateway bridge". Proceedings: 7th Austroads Bridge Conference, Auckland, New Zealand 2009.

21. Vegvesen S: "Håndbok n400 bruprosjektering". Oslo: Vegdirektoratet, 2009.

22. Danner T \& Geiker M R: "Long-term influence of concrete surface and crack orientation on selfhealing and ingress in cracks-field observations". Nordic Concrete Research, Vol. 58, No. 1, 2018, pp. 1-16.

23. Basteskår M, Engen M, Kanstad T \& Fosså K T: "A review of literature and code requirements for the crack width limitations for design of concrete structures in serviceability limit states". Structural Concrete, Vol. 20, No. 2, 2019, pp. 678-688.

24. ACI 224: "Control of cracking in concrete structures-ACI 224r-01", American Concrete Institute, 2001.

25. Schieß1 P: "Zur frage der zulässigen rissbreite und der erforderlichen betondeckung im stahlbetonbau unter besonderer berücksichtigung der karbonatisierung des betons". Technische Universität München; 1976.

26. Debernardi P G, Guiglia M \& Taliano M: "Effect of secondary cracks for cracking analysis of reinforced concrete tie". ACI Materials Journal, Vol. 110, No. 2, 2013, pp. 207.

27. Tan R, Eileraas K, Opkvitne O, Žirgulis G, Hendriks M A, Geiker M, Brekke D E \& Kanstad T: "Experimental and theoretical investigation of crack width calculation methods for rc ties". Structural Concrete, No., 2018. 
28. Broms B B \& Lutz L A: "Effects of arrangement of reinforcement on crack width and spacing of reinforced concrete members". Proceedings: ACI Journal Proceedings, 1965, 1395-1410.

29. Illston J \& Stevens R: "Internal cracking". Concrete (London), Vol. 6, No. 7, 1972.

30. Leonhardt F: "Crack control in concrete structures, iabse surveys, no. S4/77". International Association for Bridges and Structural Engineering, No., 1977, pp. 26.

31. Nielsen M: "Beton 1-del 3, 2. Udgave (concrete structures 1-part 3)". Department of Civil Engineering, Technical University of Denmark, Lyngby; 2005.

32. Goto Y: "Cracks formed in concrete around deformed tension bars". Proceedings: ACI Journal Proceedings, 1971, 244-251.

33. Beeby A: "Crack control provisions in the new eurocode for the design of concrete structures". ACI Special Publication, Vol. 204, No., 2001, pp. 57-84.

34. Park R \& Paulay T: "Reinforced concrete structures": John Wiley \& Sons; 1975.

35. Tan R, Hendriks M A \& Kanstad T: "Evaluation of current crack width calculation methods according to eurocode 2 and fib model code 2010". In: High tech concrete: Where technology and engineering meet. edn.: Springer; 2018: 1610-1618.

36. Base G D, Read J B, Beeby A \& Taylor H: "An investigation of the crack control characteristics of various types of bar in reinforced concrete beams". In: Research Report No 18. Cement and Concrete Association, London: Cement and Concrete Association Wexham Springs, Slough England; 1966.

37. Borges J F: "Cracking and deformability of reinforced concrete beams": Laboratório Nacional de Engenharia Civil; 1965.

38. Base G D, Read J B, Beeby A \& Taylor H: "An investigation of the crack control characteristics of various types of bar in reinforced concrete beams": Cement and Concrete Association, Wexham Springs, Slough, England; 1966.

39. de Saint-Venant M: "Mémoire sur la torsion des prismes: Avec des considérations sur leur flexion ainsi que sur l'équilibre intérieur des solides élastiques en général: Et des formules pratiques pour le calcul de leur résistance à divers efforts s' exerçant simultanément": Imprimerie nationale; 1856.

40. Beeby A W: "The influence of the parameter $\phi / \rho$ eff on crack widths". Structural Concrete, Vol. 5, No. 2, 2004, pp. 71-83.

41. Saliger R: "High grade steel in reinforced concrete". Proceedings: Second Congress of IABSE, Berlin-Munich 1936.

42. Watstein D \& Parsons D: "Width and spacing of tensile cracks in axially reinforced concrete cylinders". Journal of Research, National Bureau of Standards, Vol. 31, No. 1, 1943, pp. 1-24.

43. Naotunna C N, Samarakoon S M S M K \& Fosså K T: "Experimental and theoretical behavior of crack spacing of specimens subjected to axial tension and bending.". Structural Concrete, Vol. 1-18, No., 2020.

44. Beeby A \& Scott R: "Cracking and deformation of axially reinforced members subjected to pure tension". Magazine of Concrete Research, Vol. 57, No. 10, 2005, pp. 611-621.

45. Taliano M: "Cracking analysis of concrete tie reinforced with two diameter bars accounting for the effect of secondary cracks". Engineering Structures, Vol. 144, No., 2017, pp. 107-119.

46. Rots J G \& Blaauwendraad J: "Crack models for concrete, discrete or smeared? Fixed, multidirectional or rotating?". In: Heron. Edited by Seven-Laboratory, vol. 34. Netherlands: Delft University of Technology; 1989.

47. Unanwa $\mathrm{C} \&$ Mahan M: "Statistical analysis of concrete compressive strengths for california highway bridges". Journal of Performance of Constructed Facilities, Vol. 28, No. 1, 2012, pp. 157-167.

48. Naotunna C N, Samarakoon S M S M K \& Fosså K T: "Comparison of the experimental crack spacing behaviour with the theorotical predictions". In: The Nordic Concrete Federation. Oslo, Norway; 2019.

49. Gergely P \& Lutz L A: "Maximum crack width in reinforced concrete flexural members". Material Science Special Publication, Vol. 20, No., 1968, pp. 87-117.

50. Beeby A W: "An investigation of cracking in slabs spanning one way". In: Cement and Concrete Association. 1970.

51. Borosnyói A \& Snóbli I: "Crack width variation within the concrete cover of reinforced concrete members". Épitõanyag, Vol. 62, No. 3, 2010, pp. 70-74.

52. Husain S I \& Ferguson P M: "Flexural crack width at the bars in reinforced concrete beams". In. Center for Highway Research: The University of Texas at Austin; 1968. 
53. Tammo K \& Thelandersson S: "Crack opening near reinforcement bars in concrete structures". Structural Concrete, Vol. 7, No. 4, 2006, pp. 137-143.

54. Naotunna C N, Samarakoon S M S M K \& Fosså K T: "Experimental investigation of crack width variation along the concrete cover depth in reinforced concrete specimens with ribbed bars and smooth bars". Case Studies in Construction Materials, No., 2021.

55. Pérez Caldentey A, Corres Peiretti H, Peset Iribarren J \& Giraldo Soto A: "Cracking of rc members revisited: Influence of cover, $\phi / \rho$ s, ef and stirrup spacing-an experimental and theoretical study". Structural Concrete, Vol. 14, No. 1, 2013, pp. 69-78.

56. Debernardi P G \& Taliano M: "An improvement to eurocode 2 and fib model code 2010 methods for calculating crack width in re structures". Structural Concrete, Vol. 17, No. 3, 2016, pp. 365-376.

57. Tammo K \& Thelandersson S: "Crack behavior near reinforcing bars in concrete structures". ACI Structural Journal, Vol. 106, No. 3, 2009, pp. 259.

58. Wang J J, Tao M X \& Nie X: "Fracture energy-based model for average crack spacing of reinforced concrete considering size effect and concrete strength variation". Construction and Building Materials, Vol. 148, No., 2017, pp. 398-410.

59. Oh H J, Cho Y K \& Kim S-M: "Experimental evaluation of crack width movement of continuously reinforced concrete pavement under environmental load". Construction and Building Materials, Vol. 137, No., 2017, pp. 85-95.

60. DIN: "En-1992-1-1/NA. 2011-01, National Annex - Nationally determined parameters - Eurocode 2: Design of concrete structures-part 1-1: General rules and rules for buildings. DIN construction standards committee ", Beuth Verlag GmbH, Berlin; 2011.

61. Broms B B: "Crack width and crack spacing in reinforced concrete members". Proceedings: ACI Journal Proceedings, 1965, 1237-1256.

62. Naotunna C N, Samarakoon S M S M K \& Fosså K T: "Comparison of the behavior of crack widthgoverning parameters with existing models". In: Proceedings of the International Conference on Sustainable Materials, Systems and Structures (SMSS2019) vol. Rilem Publications.Vol. 4; 2019: 124-131.

63. Rimkus A \& Gribniak V: "Experimental investigation of cracking and deformations of concrete ties reinforced with multiple bars". Construction and Building Materials, Vol. 148, No., 2017, pp. 49-61.

64. Rospars C \& Chauvel D: "Ceos. Fr experimental programme and reference specimen tests results". European Journal of Environmental and Civil Engineering, Vol. 18, No. 7, 2014, pp. 738-753.

65. Bisch P: "The ceos. Fr research project-behaviour and assessment of massive structures: Cracking and shrinkage". Proceedings: Crack width calculation methods for large concrete structures, Oslo, Norway 2017, 11.

66. Lee G Y \& Kim W: "Cracking and tension stiffening behavior of high-strength concrete tension members subjected to axial load". Advances in Structural Engineering, Vol. 12, No. 2, 2009, pp. 127137.

67. Deluce J R: "Cracking behaviour of steel fibre reinforced concrete containing conventional steel reinforcement". University of Toronto; 2011.

68. Tan R, Hendriks M A, Geiker M \& Kanstad T: "Analytical calculation model for predicting cracking behavior of reinforced concrete ties". Journal of Structural Engineering, Vol. 146, No. 2, 2020, pp. 04019206.

69. Bado M F, Casas J R \& Kaklauskas G: "Distributed sensing in reinforced concrete members for reinforcement strain monitoring, crack detection and bond-slip calculation". Engineering Structures, Vol. 226, No., 2021, pp. 111385.

70. Doerr K: "Bond behavior of ribbed reinforcement under transversal pressure". Proceedings: Nonlinear behavior of reinforced concrete structures; contributions to IASS symposium, 1978, 3-7.

71. Beconcini M L, Croce P \& Formichi P: "Influence of bond-slip on the behaviour of reinforced concrete beam to column joints". Proceedings: Proceedings of International fib Symposium "Taylor Made Concrete Structures: New Solutions for our Society", Amsterdam, 2008, 19-21.

72. Ciampi V, Eligehausen R, Bertero V V \& Popov E P: "Analytical model for deformed bar bond under generalized excitations". ACI, No., 1981. 
73. Ciampi V, Eligehausen R, Bertero V V \& Popov E P: "Analytical model for concrete anchorages of reinforcing bars under generalized excitations": College of Engineering, University of California Berkeley, CA, USA; 1982.

74. Rilem: "RC 6 bond test for reinforcement steel. 2. Pull-out test, 1983", RILEM recommendations for the testing and use of constructions materials, 1994, pp. 218-220.

75. Cervenka V, Cervenka J \& Pukl R: "Atena-a tool for engineering analysis of fracture in concrete". Sadhana, Vol. 27, No. 4, 2002, pp. 485-492.

76. Kim J K \& Park Y D: "Shear strength of reinforced higy strength concrete beams without web reinforcement". Magazine of Concrete Research, Vol. 46, No. 166, 1994, pp. 7-16.

77. Naotunna C N, Samarakoon S M S M K \& Fosså K T: "Identification of the influence of concrete cover thickness and $\emptyset / \rho$ parameter on crack spacing (forthcoming).". In: XV International Conference on Durability of Building Materials and Components. Barcelona; 2020.

78. Kaklauskas G, Ramanauskas R \& Jakubovskis R: "Mean crack spacing modelling for rc tension elements". Engineering Structures, Vol. 150, No., 2017, pp. 843-851.

79. Olsen D H \& Nielsen M P: "Ny teori til bestemmelse af revneafstande og revnevidder i betonkonstruktioner": Afdelingen for bærende konstruktioner, Danmarks tekniske højskole; 1990.

80. Marti P, Alvarez M, Kaufmann W \& Sigrist V: "Tension chord model for structural concrete". Structural Engineering International, Vol. 8, No. 4, 1998, pp. 287-298.

81. McLeod C H \& Viljoen C: "Quantification of crack prediction models in reinforced concrete under flexural loading". Structural Concrete, Vol. 20, No. 6, 2019, pp. 2096-2108.

82. Caldentey A P: "Proposal of new crack width formulas in the eurocode 2, background, experiments, etc.". Proceedings: Crack width calculation methods for large concrete structures, Oslo 2017, 17.

83. Bažant Z P \& Oh B H: "Spacing of cracks in reinforced concrete". Journal of Structural Engineering, Vol. 109, No. 9, 1983, pp. 2066-2085.

84. Radnić J \& Markota L: "Experimental verification of engineering procedures for calculation of crack width in concrete elements". International Journal for Engineering Modelling, Vol. 16, No., 2003, pp. 63-69.

85. Ouyang C \& Shah S P: "Fracture energy approach for predicting cracking of reinforced concrete tensile members". Structural Journal, Vol. 91, No. 1, 1994, pp. 69-78.

86. Shah S P, Swartz S E \& Ouyang C: "Fracture mechanics of concrete: Applications of fracture mechanics to concrete, rock and other quasi-brittle materials": John Wiley \& Sons; 1995, pp.

87. Beeby A: "The prediction and control of flexural cracking in reinforced concrete members". ACI Special Publication, Vol. 30, No., 1971, pp. 55-76.

88. Caldentey A P \& García R: "Cracking of rc structures: Differences between tension and flexure". Proceedings: Design and construction of sustainable concrete structures: causes, calculation and consequences of cracks, Oslo Norway 2019, 3.

89. García R \& Caldentey A P: "Cracking of rc: Tension vs. Flexure", Madrid: Technical University of Madrid (UPM); 2018.

90. García R \& Caldentey A P: "Influence of type of loading (tension or bending) on cracking behaviour of reinforced concrete elements. Experimental study". Engineering Structures, Vol. 222, No., 2020, pp. 111134.

91. Beeby A, Alander C, Giuriani E, Plizzari G\&Pantazopoulou S: "The influence of the parameter $\varphi /$ peff on crack widths. Author's reply and discussion". Structural Concrete (London, 1999), Vol. 6, No. 4, 2005, pp. 155-165.

92. Walraven J: "Model code 2010-first complete draft-volume 2: Model code", vol. 56: fib Fédération internationale du béton; 2010.

93. Gribniak V, Rimkus A, Caldentey A P \& Sokolov A: "Cracking of concrete prisms reinforced with multiple bars in tension-the cover effect". Engineering Structures, Vol. 220, No., 2020, pp. 110979.

94. Dawood N \& Marzouk H: "Crack width model for thick reinforced concrete plates subjected to inplane forces". Canadian Journal of Civil Engineering, Vol. 38, No. 11, 2011, pp. 1262-1273.

95. Dawood N \& Marzouk H: "Experimental evaluation of the tension stiffening behavior of hsc thick panels". Engineering Structures, Vol. 33, No. 5, 2011, pp. 1687-1697. 
96. Barre F, Bisch P, Chauvel D, Cortade J, Coste J F, Dubois J P, Erlicher S, Gallitre E, Labbé P \& Mazars J: "Control of cracking in reinforced concrete structures: Research project ceos. Fr": John Wiley \& Sons; 2016.

97. Norge S: "NS-EN 1992-1-1: 2004 and NA: 2008". "Eurocode 2", 2008.

98. Hornbostel K \& Geiker M: "Influence of cracking on reinforcement corrosion". Proceedings: Crack width calculation methods for large concrete structures, Oslo 2017, 53.

99. Makita M, Mori Y \& Katawaki K: "Marine corrosion behavior of reinforced concrete exposed at tokyo bay". ACI Special Publication, Vol. 65, No., 1980, pp. 271-290.

100. Berke N S, Dallaire M, Hicks M \& Hoopes R: "Corrosion of steel in cracked concrete". Corrosion, Vol. 49, No. 11, 1993, pp. 934-943.

101. Lin C: "Bond deterioration dueto corrosion of reinforcing steel". ACI Special Publication, Vol. 65, No., 1980, pp. 255-270.

102. Tremper B: "The corrosion of reinforcing steel in cracked concrete". Proceedings: ACI Journal Proceedings, 1947, 18 (10): 1137-1144.

103. Francois R \& Arliguie G: "Reinforced concrete: Correlation between cracking and corrosion". ACI Special Publication, Vol. 126, No., 1991, pp. 1221-1238.

104. Kahhaleh K Z: "Corrosion performance of epoxy-coated reinforcement". The University of Texas at Austin 1995.

105. Chen E, Berrocal C G, Löfgren I \& Lundgren K: "Correlation between concrete cracks and corrosion characteristics of steel reinforcement in pre-cracked plain and fibre-reinforced concrete beams". Materials and Structures, Vol. 53, No. 2, 2020, pp. 1-22.

106. Ohta T: "Corrosion of reinforcing steel in concrete exposed to sea air". ACI Special Publication, Vol. 126, No., 1991, pp. 459-478.

107. Schiessl P: "Admissible crack width in reinforced concrete structures. Contribution ii, 3-17". Proceedings: Preliminary reports Vol II, Inter-association Colloquium on the Behaviour of in Service of Concrete Structures, 1975.

108. Carević V \& Ignjatović I: "Influence of loading cracks on the carbonation resistance of rc elements". Construction and Building Materials, Vol. 227, No., 2019, pp. 116583.

109. Schieß1 P \& Raupach M: "Laboratory studies and calculations on the influence of crack width on chloride-induced corrosion of steel in concrete". Materials Journal, Vol. 94, No. 1, 1997, pp. 56-61.

110. Swamy R: "Durability of rebars in concrete.". Proceedings: The GM Idorn International Symposium on Durability of Concrete, sponsored by Committee 201 on Durability, held at the 1990 Annual ACI Convention in Toronto, Ontario, Canada, 1992.

111. Misra S \& Uomoto T: "Reinforcement corrosion under simultaneous diverse exposure conditions". ACI Special Publication, Vol. 126, No., 1991, pp. 423-442.

112. Vennesland O \& Gjoro O: "Effect of cracks in submerged concrete sea structures on steel corrosion". Materials Performance, Vol. 20, No. 8, 1981, pp. 49-51.

113. Miyagawa K O T: "Chloride corrosion of reinforcing steel in cracked concrete". ACI Special Publication, Vol. 65, No., 1980, pp. 237-254.

114. Liu W \& Wang S: "The effect of crack width on chloride-induced corrosion of steel in concrete". Advances in Materials Science and Engineering, Vol. 2017, No., 2017.

115. Houston J T, Atimtay E \& Ferguson P M: "Corrosion of reinforcing steel embedded in structural concrete": Center for Highway Research, University of Texas at Austin; 1972, pp.

116. O'Neil E F: "Study of reinforced concrete beams exposed to marine environment". ACI Special Publication, Vol. 65, No., 1980, pp. 113-132.

117. Eto S, Matsuo T, Matsumura T, Fujii T \& Tanaka M Y: "Quantitative estimation of carbonation and chloride penetration in reinforced concrete by laser-induced breakdown spectroscopy". Spectrochimica Acta Part B: Atomic Spectroscopy, Vol. 101, No., 2014, pp. 245-253.

118. Marcus P: "Corrosion mechanisms in theory and practice": CRC Press; 2011.

119. Campbell-Allen D: "The reduction of cracking in concrete". Sydney: School of Civil Engineering, University of Sydney; 1979.

120. EICC \& Favre R: "Ceb design manual on cracking and deformations": École Polytechnique Fédérale de Lausanne; 1985. 
Nordic Concrete Research - Publ. No. NCR 64 - ISSUE 1 / 2021 - Article 5, pp. 69-91

121. Johnston J: "Mechanism of vision—a review". In: Sensory evaluation of appearance of materials. edn.: ASTM International; 1973.

122. Padilla J D \& Robles F: "Human response to cracking in concrete slabs". ACI Special Publication, Vol. 30, No., 1971, pp. 43-54. 